\title{
Activity and diversity of methane-oxidizing bacteria in glacier forefields on siliceous and calcareous bedrock
}

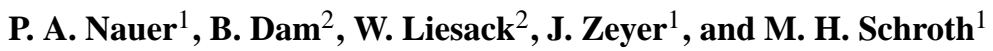 \\ ${ }^{1}$ Institute of Biogeochemistry and Pollutant Dynamics, ETH Zurich, 8092 Zurich, Switzerland \\ ${ }^{2}$ Max-Planck-Institute for Terrestrial Microbiology, 35043 Marburg, Germany \\ Correspondence to: M. H. Schroth (martin.schroth@env.ethz.ch)
}

Received: 11 January 2012 - Published in Biogeosciences Discuss.: 30 January 2012

Revised: 23 April 2012 - Accepted: 1 May 2012 - Published: 25 June 2012

\begin{abstract}
The global methane $\left(\mathrm{CH}_{4}\right)$ cycle is largely driven by methanogenic archaea and methane-oxidizing bacteria (MOB), but little is known about their activity and diversity in pioneer ecosystems. We conducted a field survey in forefields of 13 receding Swiss glaciers on both siliceous and calcareous bedrock to investigate and quantify $\mathrm{CH}_{4}$ turnover based on soil-gas $\mathrm{CH}_{4}$ concentration profiles, and to characterize the MOB community by sequencing and terminal restriction fragment length polymorphism (T-RFLP) analysis of $p m o A$. Methane turnover was fundamentally different in the two bedrock categories. Of the $36 \mathrm{CH}_{4}$ concentration profiles from siliceous locations, 11 showed atmospheric $\mathrm{CH}_{4}$ consumption at concentrations of $\sim 1-2 \mu \mathrm{LL}^{-1}$ with soilatmosphere $\mathrm{CH}_{4}$ fluxes of -0.14 to $-1.1 \mathrm{mg} \mathrm{m}^{-2} \mathrm{~d}^{-1}$. Another 11 profiles showed no apparent activity, while the remaining 14 exhibited slightly increased $\mathrm{CH}_{4}$ concentrations of $\sim 2-10 \mu \mathrm{LL}^{-1}$, most likely due to microsite methanogenesis. In contrast, all profiles from calcareous sites suggested a substantial, yet unknown $\mathrm{CH}_{4}$ source below our sampling zone, with soil-gas $\mathrm{CH}_{4}$ concentrations reaching up to $1400 \mu \mathrm{LL}^{-1}$. Remarkably, most soils oxidized $\sim 90 \%$ of the deep-soil $\mathrm{CH}_{4}$, resulting in soil-atmosphere fluxes of 0.12 to $31 \mathrm{mg} \mathrm{m}^{-2} \mathrm{~d}^{-1}$. MOB showed limited diversity in both siliceous and calcareous forefields: all identified pmoA sequences formed only 5 operational taxonomic units (OTUs) at the species level and, with one exception, could be assigned to either Methylocystis or the as-yet-uncultivated Upland Soil Cluster $\gamma$ (USC $\gamma$ ). The latter dominated T-RFLP patterns of all siliceous and most calcareous samples, while Methylocystis dominated in 4 calcareous samples. Members of Upland Soil Cluster $\alpha$ (USC $\alpha$ ) were not detected. Apparently, USC $\gamma$ adapted best to the oligotrophic cold climate conditions at the investigated pioneer sites.
\end{abstract}

\section{Introduction}

Methane is a major contributor to recent changes in the global climate system (Forster et al., 2007). Since preindustrial times, its concentration in the atmosphere has more than doubled and, after appearing to approach a steady state in the early 2000s, has continued to rise again to a global average of $1.80 \mu \mathrm{L} \mathrm{L}^{-1}$ (Dlugokencky et al., 2009). Whether influenced by anthropogenic activities or not, the terrestrial $\mathrm{CH}_{4}$ cycle is largely driven by microorganisms (Conrad, 2009). Methane is produced by strictly anaerobic methanogens that convert products from anaerobic breakdown of organic matter to $\mathrm{CH}_{4}$ (Conrad, 1996). However, only a fraction of produced $\mathrm{CH}_{4}$ actually reaches the atmosphere, while a large part is transformed to $\mathrm{CO}_{2}$ by methaneoxidizing bacteria (MOB) in the transition zone between the anaerobic habitat and the atmosphere (De Visscher et al., 2007; Conrad, 2009). The aerobic MOB diversity occurring in such transition zones is well represented by cultured bacteria, which are Gram-negative and belong to either the Gammaproteobacteria (Type I), Alphaproteobacteria (Type II) or, as recently discovered, to the phylum Verrucomicrobia (Hanson and Hanson, 1996; Dunfield et al., 2007). Anaerobic $\mathrm{CH}_{4}$ oxidation might also be widespread; so far it has been reported for a sulfate-reducing consortium of archaea (e.g. Boetius et al., 2000; Orphan et al., 2002) and for "Candidatus Methylomirabilis oxyfera", an anaerobic nitrite reducer of the phylum NC10 that produces its own oxygen (Ettwig et al., 2010). However, in this paper we focus on aerobic MOB in unsaturated, well-aerated (upland) soils.

Upland soils have been observed to consume atmospheric $\mathrm{CH}_{4}$ in all climate zones, including cold environments like tundra, boreal forests and alpine meadows (e.g. Whalen and Reeburgh, 1990; Adamsen and King, 1993; Smith et al., 
2000; Flessa et al., 2008; Hartmann et al., 2010). In upland soils, $\mathrm{CH}_{4}$ uptake seemed to follow Michaelis-Menten kinetics with low $K_{m}$-values (Bender and Conrad, 1992). It is hypothesized that specialized "high-affinity" MOB living on trace levels of $\mathrm{CH}_{4}$ and, to a lesser extent, alphaproteobacterial Methylocystis spp. are responsible for this sole terrestrial sink of atmospheric $\mathrm{CH}_{4}$ (Dunfield, 2007). Cultivation attempts for specialized high-affinity MOB have been unsuccessful to date (Kolb, 2009). Evidence of their identity was gained through molecular analyses based on the functional gene $p m o A$ that encodes for a subunit of the particulate methane monooxygenase (pMMO). This enzyme catalyzes the first step of $\mathrm{CH}_{4}$ oxidation, i.e. the conversion of $\mathrm{CH}_{4}$ to methanol, and is present in almost all known MOB (Hanson and Hanson, 1996; McDonald et al., 2008). Mainly two novel groups of $p m o A$ sequences have been identified in soils consuming atmospheric $\mathrm{CH}_{4}$. The first group detected, Upland Soil Cluster $\alpha$ (USC $\alpha$ ), represents Type-IIrelated MOB, with Methylocapsa acidiphila as their closest cultivated MOB (Holmes et al., 1999; Henckel et al., 2000; Knief et al., 2003; Kolb et al., 2005). They were predominantly found in acidic forest soils. The second group, USC $\gamma$, is comprised of $p m o A$ sequences most closely related to Type I Methylococcaceae and was found in soils with neutral to basic pH values (Knief et al., 2003; Zheng et al., 2011). In addition, pmoA from Methylocystis was frequently identified in soils oxidizing atmospheric $\mathrm{CH}_{4}$ (e.g. Knief et al., 2003). Some isolated strains like Methylocystis sp. strain SC2 show the capability of growth at $\mathrm{CH}_{4}$ concentrations of 10$100 \mu \mathrm{LL}^{-1}$ (Knief and Dunfield, 2005; Baani and Liesack, 2008). The ability of strain $\mathrm{SC} 2$ to grow at such low $\mathrm{CH}_{4}$ concentrations is related to the presence of a high-affinity form of pMMO (encoded by pmoCAB2). The high-affinity pMMO2 even oxidized methane at atmospheric $\mathrm{CH}_{4}$ concentrations, contrary to the conventional pMMO1 (encoded by pmoCAB1) that oxidized $\mathrm{CH}_{4}$ only at concentrations above 600-700 $\mu \mathrm{LL}^{-1}$ (Baani and Liesack, 2008). It is hypothesized that Methylocystis exhibits a "flush-feeding" strategy: it grows and acquires storage compounds during phases of elevated $\mathrm{CH}_{4}$ concentrations while maintaining cell function with consumption of atmospheric $\mathrm{CH}_{4}$ (Dunfield, 2007; Kolb, 2009).

Molecular evidence for the presence of $p m o A$ provides no information on the magnitude of MOB activity. It is important to accompany molecular ecology techniques by in-situ measurements of $\mathrm{CH}_{4}$ turnover to assess if MOB are part of the active bacterial community and to provide hands-on information for ecosystem modeling. Most studies investigating $\mathrm{CH}_{4}$ turnover in situ use the closed-chamber approach and measure $\mathrm{CH}_{4}$ fluxes across the soil-atmosphere boundary (e.g. Smith et al., 2000). These net fluxes represent a bulk measurement of three underlying processes: physical transport (dominantly diffusion), $\mathrm{CH}_{4}$ oxidation by $\mathrm{MOB}$ and $\mathrm{CH}_{4}$ production by methanogens. While the conventional chamber method cannot distinguish between the three pro- cesses, the soil- $\mathrm{CH}_{4}$ profile method, i.e. extraction of soil gas at different depths and subsequent analysis of $\mathrm{CH}_{4}$ concentrations, provides qualitative information about $\mathrm{CH}_{4}$ production and consumption zones (Yavitt et al., 1990). Under certain conditions it can also be used to quantify the magnitude of $\mathrm{CH}_{4}$ oxidation and production (Born et al., 1990; Fechner and Hemond, 1992). Soil physical transport parameters, i.e. the effective diffusion coefficient of $\mathrm{CH}_{4}$ in soil $D_{\text {eff }}\left(\mathrm{cm}^{2}\right.$ $\min ^{-1}$ ), can be estimated through concomitant measurement of total soil porosity $\theta_{\mathrm{t}}$ and volumetric water content $\theta_{\mathrm{w}}$ using empirical relationships (e.g. Kristensen et al., 2010).

Terrestrial $\mathrm{CH}_{4}$ turnover has been well investigated in developed soils, but surprisingly little is known about magnitude and dynamics of the underlying processes in pioneer ecosystems. In alpine environments, the rapid retreat of many glaciers creates excellent study sites for microbial colonization, diversity and functional strategies (Sigler and Zeyer, 2002; Nemergut et al., 2007; Lazzaro et al., 2009; Brankatschk et al., 2010; Lazzaro et al., 2011). After glacier meltdown, the creation of a well-aerated vadose zone in recently exposed glacier sediments (termed "glacier forefield") might imply an advantage for high-affinity MOB, as they are able to cover their carbon and energy needs from the atmosphere in an otherwise C-limited environment. Additionally, the presence of anoxic conditions in young glacier forefields seems to be widespread (Wadham et al., 2007), and there is evidence of locally confined buried organic carbon, e.g. subfossil wood and peat disks (Hormes et al., 2001; Joerin et al., 2006). Such circumstances might enhance microsite methanogenesis and opportunistic flush-feeding MOB. Limitations of $\mathrm{N}$ in glacier forefields might be overcome by the ability of many MOB to fix $\mathrm{N}_{2}$ (Auman et al., 2001; Dedysh et al., 2004). Accordingly, a recent study investigating nifHgene diversity of $\mathrm{N}_{2}$-fixing bacteria in a Swiss glacier forefield affiliated $16 \%$ of total diversity to MOB (Duc et al., 2009).

We therefore hypothesized that glacier forefield soils may exhibit low but measurable consumption of $\mathrm{CH}_{4}$ through the activity of high-affinity and flush-feeding MOB. To investigate the extent and magnitude of $\mathrm{CH}_{4}$ oxidation in Swiss Alpine glacier forefields, we conducted a field survey in 13 forefields with different site characteristics. Special attention was given to adequately represent the two main types of subglacial bedrock in the Swiss Alps: siliceous and calcareous. Due to the contrasting weathering mechanisms and soil properties (especially $\mathrm{pH}$ ) of the two bedrock types (Lazzaro et al., 2009), we also hypothesized differences between the respective MOB communities, in particular occurrence of USC $\alpha$ in acidic and USC $\gamma$ in neutral and basic soils. Specific objectives of the survey were i) to investigate recently exposed soils in different glacier forefields for $\mathrm{CH}_{4}$ turnover and quantify $\mathrm{CH}_{4}$ fluxes using the soil- $\mathrm{CH}_{4}$ profile method; (ii) to screen these soils for the presence of $p m o A$ and investigate the diversity of indigenous MOB with molecular-ecology techniques; and (iii) to characterize 
sampled forefields in terms of soil physical and chemical properties, and relate potential activity and diversity patterns to relevant parameters.

\section{Materials and methods}

\subsection{Field sites}

All sampling took place in summer and autumn 2010 during dry weather conditions. Study sites comprised forefields of 13 receding glaciers in the Swiss Alps (Table 1). Our focus for site selection lay on glaciers that had a forefield with moderate to low steepness featuring fractionated gravel, sand and silt patches, rather than just pure bedrock. The main criteria for choosing sampling locations in each forefield were the possibility of extracting soil gas from depths $>30 \mathrm{~cm}$, relatively close proximity to the glacier terminus $(\sim 100$ to $200 \mathrm{~m}$ ) and the absence of plant cover. As a consequence mainly of the first criterion, sampled locations throughout all forefields lay in similarly structured patches with minimal skeletal or rock fraction (compared to the rest of the forefield). Hence, although sampled locations are representative only for parts of the respective forefield, they are comparable across sites. Locations are referred to by site abbreviation followed by sampling sequence number (Table 1). Sampled soils may be classified as lithic/skeletic leptosols (IUSS Working Group, 2006), exhibiting a low level of aggregation. The respective soil age (i.e. the duration since exposure to the atmosphere; Table 1) was determined from historical cartographical material (Swiss Federal Office of Topography, Wabern, Switzerland).

\subsection{Soil and soil-gas sampling}

Soil gas was extracted through a custom-made 2-cm o.d. stainless steel rod of $80 \mathrm{~cm}$ total length, featuring a $1-\mathrm{mm}$ i.d. capillary. The tip of the rod comprised four conical holes of $8 \mathrm{~mm}$ o.d., reduced to $1 \mathrm{~mm}$ i.d. at $5 \mathrm{~mm}$ depth, which were connected to the inner capillary. The rod was gradually hammered into the soil in steps of $5 \mathrm{~cm}(10 \mathrm{~cm}$ after $50 \mathrm{~cm}$ depth), until we reached the maximum sampling depth of $70 \mathrm{~cm}$, or hit a boulder. At each step, we extracted $20 \mathrm{~mL}$ soil gas with a plastic syringe (after discarding the first $10 \mathrm{~mL}$ ), then injected it into a gas-tight sampling vial previously $\mathrm{N}_{2}$-flushed and evacuated. Pressure was measured before and after injection to account for dilution. Due to time constraints and the destructive nature of the sampling procedure, no replicates of soil-gas samples could be taken. Methane was measured on a GC-FID system described in Nauer and Schroth (2010). Oxygen was measured according to Urmann et al. (2007) in samples of the two profiles that showed the highest $\mathrm{CH}_{4}$ concentrations (WIL 4 and 5).

For molecular and chemical analyses, soil was sampled from $3-10 \mathrm{~cm}$ depth, presumably the layer with the highest activity of high-affinity MOB (e.g. Adamsen and King,
1993). Due to low soil aggregation, we used spoons, previously washed in commercial bleach and autoclaved, to sample from 4-5 spots in close vicinity to where the soil-gas profile was taken. For each location, the soil was then pooled into one mixed sample and stored on ice until arrival in the lab. For molecular analyses, soil was transferred into a falcon tube and freeze-dried. Fresh soil extracts of $10 \mathrm{~g}$ soil in $25 \mathrm{~mL} 1 \mathrm{M} \mathrm{KCl}$ solution and $1 \mathrm{~g}$ soil in $10 \mathrm{~mL}$ distilled water were prepared and put on an overhead shaker for $1 \mathrm{~h}$ and overnight, respectively. The extracts were filtered with $0.45 \mu \mathrm{m}$ nylon filters and frozen until further analysis. The rest of the sample was dried for $72 \mathrm{~h}$ at $60^{\circ} \mathrm{C}$ and stored at room temperature.

\subsection{Soil physical and chemical properties}

After soil and soil-gas sampling had been completed, temperature and $\theta_{\mathrm{w}}$ from $0-10 \mathrm{~cm}$ depth were measured in the field with a handheld TDR probe (Hydrosense ${ }^{\mathrm{TM}}$ System, Campbell Scientific, Logan, UT, USA). For determination of soil bulk density, we used an adapted PU-foam method suitable for soils with a high skeletal fraction (Muller and Hamilton, 1992). In a quadratic frame of $12-\mathrm{cm}$ edge length, we excavated approximately $1 \mathrm{~L}$ of soil to a depth of $10-15 \mathrm{~cm}$. The excavation was then filled with one-component closed-cell PU foam (SOUDAL Mega Schaum, SOUDAL N.V., Turnhout, Belgium) and left to cure for at least $2 \mathrm{~h}$. The volume of the excavation cast was later determined by water displacement. Soil sampled in this way was weighted in the field, then dried in the lab for $72 \mathrm{~h}$ at $60^{\circ} \mathrm{C}$ for an additional measure of $\theta_{\mathrm{w}}$ and particle density, to estimate $\theta_{\mathrm{t}}$ and water saturation $S_{\mathrm{w}}$. We compared the method against a core-sampling procedure in a homogenous sandy soil, where it gave consistent results (standard deviation $\mathrm{sd}= \pm 2.5 \%$ ). From the same samples we determined grain-size distribution using a laserdiffraction particle size analyzer (LS 13320, Beckman Coulter Inc., Brea, CA, USA). TDR measurements were erratic and consistently lower than estimated from PU-foam samples, due to the high skeleton fraction of many soils. These values were therefore only used if no PU-foam samples could be taken due to time constraints (i.e. complete curing of the foam was not possible).

The $\mathrm{KCl}$ extracts were used to determine soil $\mathrm{pH}$ (Soil Survey Staff, 2011) with a Mettler Toledo $830 \mathrm{pH}$ meter (Mettler Toledo, Greifensee, Switzerland), nitrate, sulfate and phosphate by ion chromatography (IC-320, Dionex, Sunnyvale, CA, USA), and ammonium colorimetrically using the protocol of Sims et al. (1995). DOC in the water extracts was determined on a Shimadzu TOC-5000 analyzer (Shimadzu SSI, Columbia, MD, USA) after acidification with $40 \mu \mathrm{L}$ of $35 \%$ $\mathrm{HCl}$. Total elemental contents, except carbon, were measured by X-ray fluorescence (XRF) analysis (Spectro-X-Lab 2000, Spectro, Kleve, Germany), in pellets of $4 \mathrm{~g}$ of milled soil mixed with $0.9 \mathrm{~g}$ Hoechst wax. Total carbon (TC) and total inorganic carbon (IC) were measured on a coulometer 
Table 1. Overview of sampled glacier forefields and site characteristics. The date of sampling (dd.mm.) for each site is followed by the number of locations sampled on this date in parentheses. Soil age is reported in sampling sequence for each location.

\begin{tabular}{|c|c|c|c|c|c|c|c|c|}
\hline \multirow[b]{2}{*}{ Glacier } & \multirow{2}{*}{$\begin{array}{l}\text { Site } \\
\text { abbrev. }\end{array}$} & \multicolumn{2}{|c|}{$\begin{array}{c}\text { Coordinates } \\
\text { WGS84 }\end{array}$} & \multirow{2}{*}{$\begin{array}{r}\text { Altitude } \\
\text { (terminus) } \\
\text { ma.s.l. }\end{array}$} & \multirow{2}{*}{$\begin{array}{l}\text { Average } \\
\text { rainfall }^{\mathrm{a}} \\
\mathrm{mm} \mathrm{yr}^{-1}\end{array}$} & \multirow{2}{*}{$\begin{array}{c}\text { Bedrock } \\
\text { type }\end{array}$} & \multirow{2}{*}{$\begin{array}{c}\text { Sampling } \\
\text { dates in } 2010 \\
\text { (no. of locations) }\end{array}$} & \multirow{2}{*}{$\begin{array}{l}\text { Maximum } \\
\text { soil age }^{b} \\
\text { (yr) }\end{array}$} \\
\hline & & $\mathrm{N}$ & $\mathrm{E}$ & & & & & \\
\hline Unterer Arolla & BAR & $45^{\circ} 59^{\prime} 52^{\prime \prime}$ & $7^{\circ} 29^{\prime} 39^{\prime \prime}$ & 2150 & 727 & \multirow{9}{*}{ 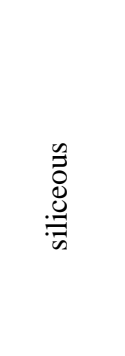 } & 30.07. (4) & $20,20,20,10$ \\
\hline Damma & DAM & $46^{\circ} 38^{\prime} 10^{\prime \prime}$ & $8^{\circ} 27^{\prime} 24^{\prime \prime}$ & 2100 & 1559 & & 12.10. (4) & $20,20,20,20$ \\
\hline Forno & FOR & $46^{\circ} 20^{\prime} 20^{\prime \prime}$ & $9^{\circ} 41^{\prime} 60^{\prime \prime}$ & 2250 & 1462 & & 04.07. (5) & $5,5,5,20,20$ \\
\hline Mont-Miné & MOM & $46^{\circ} 02^{\prime} 39^{\prime \prime}$ & $7^{\circ} 33^{\prime} 12^{\prime \prime}$ & 2000 & 727 & & 28.07. (4) & $10,10,10,10$ \\
\hline Morteratsch & MRT & $46^{\circ} 25^{\prime} 45^{\prime \prime}$ & $9^{\circ} 56^{\prime} 05^{\prime \prime}$ & 2050 & 811 & & 03.07. (7) & $5,5,5,5,5,20,>50$ \\
\hline \multirow[t]{2}{*}{ Stein } & STI & $46^{\circ} 43^{\prime} 14^{\prime \prime}$ & $8^{\circ} 26^{\prime} 01^{\prime \prime}$ & 2000 & 1661 & & 18.06. (3) & $10,5,5$ \\
\hline & & & & & & & 16.07. (1) & 10 \\
\hline Steinlimi & STL & $46^{\circ} 42^{\prime} 39^{\prime \prime}$ & $8^{\circ} 24^{\prime} 42^{\prime \prime}$ & 2200 & 1661 & & 16.07. (4) & $5,5,5,5$ \\
\hline Tschierva & TSV & $46^{\circ} 24^{\prime} 22^{\prime \prime}$ & $9^{\circ} 51^{\prime} 48^{\prime \prime}$ & 2300 & 811 & & 02.07. (4) & $10,10,10,20$ \\
\hline Claridenfirn & CLF & $46^{\circ} 51^{\prime} 12^{\prime \prime}$ & $8^{\circ} 55^{\prime} 25^{\prime \prime}$ & 2600 & 1802 & \multirow{7}{*}{ 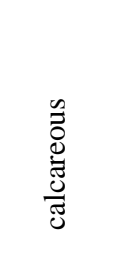 } & 22.09. (3) & $5,5,5$ \\
\hline Griessfirn & GRF & $46^{\circ} 50^{\prime} 37^{\prime \prime}$ & $8^{\circ} 49^{\prime} 45^{\prime \prime}$ & 2250 & 1798 & & 10.08. (4) & $20,20,20,20$ \\
\hline Griessen & GRI & $46^{\circ} 50^{\prime} 52^{\prime \prime}$ & $8^{\circ} 29^{\prime} 07^{\prime \prime}$ & 2500 & 1591 & & 07.07. (4) & all $>50$ \\
\hline \multirow{3}{*}{ Im Griess } & & & & & & & 04.08. (1) & \\
\hline & KLG & $46^{\circ} 51^{\prime} 31^{\prime \prime}$ & $8^{\circ} 52^{\prime} 23^{\prime \prime}$ & 2100 & 1789 & & 09.07. (2) & 10,01 \\
\hline & & & & & & & 21.07. (4) & $50,50,>50,>50$ \\
\hline Wildstrubel & WIL & $46^{\circ} 23^{\prime} 54^{\prime \prime}$ & $7^{\circ} 33^{\prime} 42^{\prime \prime}$ & 2600 & 1099 & & 26.08. (5) & $40,40,40,40,10$ \\
\hline
\end{tabular}

a Data are from the closest precipitation monitoring station of MeteoSwiss (https://gate.meteoswiss.ch/idaweb, last access on 5 December 2011); station overview: http://www.meteoschweiz.admin.ch/web/en/climate/observation_systems/surface.Par.0047.DownloadFile.tmp/listofprecipitationmonitoringnetwork.pdf.

b Years since last record of ice coverage, rounded to 5-yr intervals.

(CM 5012, UIC Inc., Joliet, IL, USA) using $~ 10$ to $20 \mathrm{mg}$ of milled soil. For TC, the samples were pyrolysed at $950^{\circ} \mathrm{C}$ in an autosampler furnace (CM 5200), whereas for IC they were acidified with $2 \mathrm{~N}$ perchloric acid in an acidification module (CM 5130). Due to high variance of replicate measurements (sd up to $\pm 0.5 \%$ for siliceous, and $\pm 0.3 \%$ for calcareous samples), organic carbon ( $\mathrm{OC}=\mathrm{TC}-\mathrm{IC}$ ) was not reported, as computed values were below this threshold.

\subsection{DNA extraction and amplification}

A total of 27 samples were chosen for molecular analysis, comprising two or three freeze-dried subsamples from each of the 13 sites. The subsamples were chosen according to the greatest differences in $\mathrm{CH}_{4}$ concentrations at $10 \mathrm{~cm}$ depth. The extraction of total DNA was performed using the MP FastDNA®Spin Kit for Soil (MP Biomedicals, Solon, $\mathrm{OH}$, USA), with some minor modifications. Instead of the protein precipitation step as suggested by the manufacturer, the soil homogenate was incubated with proteinase $\mathrm{K}$ at $68^{\circ} \mathrm{C}$ for $30 \mathrm{~min}$. The DNA was successively extracted with (i) phenol (saturated with $10 \mathrm{mM}$ Tris $\mathrm{pH}$ 8.0, $1 \mathrm{mM}$ EDTA), (ii) phenol-chloroform (1:1 [ $\mathrm{vol} / \mathrm{vol}])$, and (iii) chloroformisoamyl alcohol (24:1 [vol/vol]). The final supernatant was then mixed with the binding matrix supplied by the MP FastDNA®Spin Kit, and the remaining steps were performed as specified in the user manual. DNA yield ranged between
1 to $2 \mu \mathrm{g}$ (g d.w. $)^{-1}$. Sufficient purity of all the DNA extracts was confirmed by measurement of the 260/280 ratio that ranged between 1.6 and 1.8 (NanoDrop ND-1000 spectrophotometer, NanoDrop Technologies, Wilmington, DE, USA). In addition, the amplifiability of all the DNA extracts was tested by PCR amplification of bacterial 16S rRNA genes using the primer pair 27f and 1492r (Lane, 1991).

In first-round PCR of $p m o A$, we employed the forward primer A189f in combination with reverse primers A682r, mb661 and A650r (Holmes et al., 1995; Costello and Lidstrom, 1999; Bourne et al., 2001). PCR was run using a touch-down program: initial denaturation $\left(94^{\circ} \mathrm{C}, 4 \mathrm{~min}\right)$, followed by 10 cycles of denaturation $\left(94^{\circ} \mathrm{C}, 1 \mathrm{~min}\right)$, primer annealing at $62^{\circ} \mathrm{C}$ for $1 \mathrm{~min}$ (reduced by $1^{\circ} \mathrm{C}$ each cycle to a "touchdown" temperature at $\left.52^{\circ} \mathrm{C}\right)$, and elongation $\left(72^{\circ} \mathrm{C}\right.$, $1 \mathrm{~min})$. Additional 20 cycles were run using the same thermal profile with an annealing temperature of $52{ }^{\circ} \mathrm{C}$. The final elongation step was extended to $7 \mathrm{~min}$. Due to the failure to obtain PCR amplicons from all 27 DNA extracts in the first round, nested PCR was performed with the forward primers A189f and pmoA206f (Tchawa Yimga et al., 2003) combined with either mb661 or A650r, using $1 \mu \mathrm{L}$ of the PCR product of primer set A189f-A682r as template. The thermal profile of second-round PCR consisted of an initial denaturation $\left(94^{\circ} \mathrm{C}, 4 \mathrm{~min}\right)$, followed by 22 cycles of denaturation $\left(94^{\circ} \mathrm{C}, 1 \mathrm{~min}\right)$, primer annealing $\left(56^{\circ} \mathrm{C}, 1 \mathrm{~min}\right)$, and elongation $\left(72^{\circ} \mathrm{C}, 1 \mathrm{~min}\right)$. PCR amplification was carried out using 
a reaction mixture containing $1 \mu \mathrm{l}$ of template DNA, $10 \mu \mathrm{l}$ of $5 \times$ GoTaq Flexi reaction buffer (Promega, Mannheim, Germany), $1.5 \mathrm{mM} \mathrm{MgCl} 2,200 \mathrm{mM}$ each dNTP, $5 \mu \mathrm{g}$ of bovine serum albumin (Promega), $0.5 \mu \mathrm{M}$ of each primer, and $2.5 \mathrm{U}$ of Flexi Taq DNA polymerase (Promega). PCR was performed after adjusting the total volume to $50 \mu \mathrm{l}$ with sterile $\mathrm{H}_{2} \mathrm{O}$, using a DNA thermal cycler (Applied Biosystems, Foster City, CA,USA).

\subsection{Analysis of pmoA amplicons}

Four pmoA clone libraries were constructed from composite $p m o A$ amplicons generated by nested PCR from FOR 1, GRF 2, MRT 7, and mixed WIL 1, 4 and 5. Cloning was done using the pGEM-T Easy cloning kit (Promega) according to the manufacturer's protocol. In total, $82 \mathrm{pmoA}$ sequences were selected for analysis ( 8 from FOR 1, 21 from GRF 2, 19 from MRT 7, and 35 from WIL $1+$ WIL 4 + WIL 5). Cloned inserts (508 bp) were completely sequenced using the BigDye V3.1 terminator chemistry (Applied Biosystems). The identities of the $p m o A$ gene sequences were confirmed by searching public sequence databases using BLASTN (http://www.ncbi.nlm.nih.gov/BLAST/). Phylogenetic analyses at the DNA and deduced amino acid sequence levels were carried out using the ARB program package (Ludwig et al., 2004). pmoA sequences obtained in the course of this study were aligned to a manually curated $p m o A$ database containing $>3000$ sequences. Regions of sequence ambiguity and incomplete data were excluded from the analyses. Trees were constructed using the neighbor-joining and maximum-likelihood methods. Representative pmoA gene sequences of each species-level OTU have been deposited in the EMBL, GenBank and DDBJ nucleotide databases under the accession numbers HE647840 to HE647850.

T-RFLP fingerprint patterns were generated in triplicate for each DNA sample. PCR was performed with the forward primer (A189f or pmoA206f) being FAM (6carboxyfluorescein) -labeled. The $p m o A$ PCR products were gel purified by using Wizard SV Gel and PCR Cleanup System (Promega) according to the supplier's protocol. Approximately $100 \mathrm{ng}$ of each $p m o A$ amplicon was digested with 10 $\mathrm{U}$ of the restriction endonuclease MspI (Promega). The digestion was carried out in a total volume of $10 \mu \mathrm{L}$ for $12 \mathrm{~h}$ at $37^{\circ} \mathrm{C}$. The restriction digests were purified using Illustra AutoSeq G-50 columns (GE Healthcare UK Limited, Little Chalfont, UK). Aliquots $(2.5 \mu \mathrm{l})$ of the digested amplicons were mixed with $12 \mu \mathrm{L}$ of deionized formamide (Applied Biosystems) and $0.3 \mu \mathrm{L}$ of an internal DNA fragment length standard (MapMarker®1000; BioVentures, Murfreesboro, TN, USA). The mixtures were denatured at $94^{\circ} \mathrm{C}$ for 3 min and then chilled on ice. The fluorescently labeled terminal restriction fragments (T-RFs) were size-separated on an ABI 3100 capillary sequencer (Applied Biosystems). The length of each fluorescently labeled T-RF was determined by comparison with the internal standard using GeneScan 3.71 software (Applied Biosystems). The accuracy of size calling between replicates was $\pm 1 \mathrm{bp}$. The relative abundance of TRFs in a given T-RFLP pattern was determined as the peak height of the respective T-RF divided by the total peak height of all T-RFs detected within a fragment size range between 50 and $510 \mathrm{bp}$, and was expressed as percentages (Dunbar et al., 2001; Shrestha et al., 2011).

\subsection{Analysis of soil- $\mathrm{CH}_{4}$ profiles}

Methane fluxes $J\left(\mathrm{mg} \mathrm{CH}_{4} \mathrm{~m}^{-2} \mathrm{~d}^{-1}\right)$ from deep soil $(>70 \mathrm{~cm})$ into the sampling zone $\left(J_{\mathrm{ds}}\right)$, and from there into the atmosphere $\left(J_{\text {atm }}\right)$, were approximated according to Fick's first law (e.g. Fechner and Hemond, 1992):

$J \approx D_{\text {eff }} \frac{\Delta C}{\Delta z}$

where $\Delta C / \Delta z$ is the discrete difference gradient of the 0 $5 \mathrm{~cm}$ depth interval $\left(J_{\mathrm{atm}}\right)$, or the two deepest sampling points $\left(J_{\mathrm{ds}}\right)$, respectively. If the gradient changed direction in the next interval, the mean value of three intervals was taken. From $\theta_{\mathrm{t}}$ and $\theta_{\mathrm{w}}$ we estimated $D_{\text {eff }}$ according to the WLRMarshall model (Moldrup et al., 2000):

$D_{\text {eff }}=D_{\text {air }} \theta_{\mathrm{a}}^{1.5} \frac{\theta_{\mathrm{a}}}{\theta_{\mathrm{t}}}$

where $D_{\text {air }}\left(14.9 \mathrm{~cm}^{2} \mathrm{~min}^{-1}\right.$ at $15^{\circ} \mathrm{C}$ and 0.8 bar atmospheric pressure; Fuller et al., 1966) denotes the diffusion coefficient of $\mathrm{CH}_{4}$ in air, and $\theta_{a}$ is the air-filled porosity of the respective soil $\left(\theta_{a}=\theta_{\mathrm{t}}-\theta_{\mathrm{w}}\right)$. Estimated $D_{\text {eff }}$ were computed for the first $10 \mathrm{~cm}$ of the soil, and assumed to be constant with depth. With this simplification we estimated $\mathrm{CH}_{4}$ fluxes for profiles showing spatially separated production and consumption zones, and additionally for profiles indicating atmospheric $\mathrm{CH}_{4}$ consumption.

For profiles indicating atmospheric $\mathrm{CH}_{4}$ consumption only, a simplified diffusion-consumption model was fitted to measured soil- $\mathrm{CH}_{4}$ concentrations to estimate first-order rate coefficients $k\left(\mathrm{~h}^{-1}\right)$ of $\mathrm{CH}_{4}$ oxidation (Born et al., 1990):

$C_{(z)}=C_{(\infty)}+\left(C_{(0)}-C_{\infty}\right) \exp \left(-z \sqrt{\frac{k}{D_{\text {eff }}}}\right)$.

Here, $C_{(z)}\left(\mu \mathrm{l}^{-1}\right)$ denotes $\mathrm{CH}_{4}$ concentrations at the respective depth $z, C_{(\infty)}$ is the fitted concentration at $z=\infty$, and $C_{(0)}$ is the measured above-ground concentration of $\mathrm{CH}_{4}$. Equation (3) was fitted to data using non-linear least squares with a Gauss-Newton algorithm in the $R$ environment $(R$ 2.11.1; www.r-project.org).

\subsection{Statistical analysis}

For possible explanations of MOB activity and diversity patterns, we tested individual parameters for significant differences among bedrock types, profile categories and MOB 
groups (see discussion) using analysis of variance, Pearson's chi-squared test and linear regression in $R$. The explorative design of this survey did not allow a more rigorous statistical analysis to be performed; test statistics served solely the purpose of providing hypotheses for further studies and should not be interpreted conclusively.

\section{Results}

\subsection{Soil properties}

Temperatures in $0-10 \mathrm{~cm}$ depth varied over a wide range of $4-26^{\circ} \mathrm{C}$ (Table 2), with highest values measured at STL (16 July), and lowest at DAM (12 October). Sandy soils were the most common, irrespective of bedrock type. Skeleton content was highly variable; at 13 locations it exceeded $50 \%$ (Table 2). Porosities ranged from 0.36 to 0.59 , with a mean of $0.45 \pm 0.06$ (sd), while $S_{\mathrm{w}}$ ranged from 2 to $37 \mathrm{vol} \%$, with a mean of $16 \pm 10 \mathrm{vol} \%$ and one outlier of $60 \mathrm{vol} \%$.

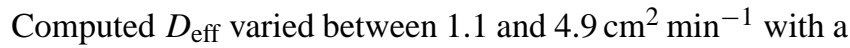
mean of $2.54 \pm 0.87 \mathrm{~cm}^{2} \mathrm{~min}^{-1}$, not counting one low outlier (0.49) from the location with highest $S_{\mathrm{w}}$, and one high outlier (6.5) from the location with the highest $\theta_{\mathrm{t}}$ and low $S_{\mathrm{w}}$.

Chemical parameters (site means) are summarized in Table 3 . Measured (potential) $\mathrm{pH}$ values were generally between 8 and 9 at all calcareous sites, and between 6 and 7.5 at siliceous sites. Exceptional siliceous sites were TSV and MOM, where sampled soils exhibited basic $\mathrm{pH}$ values, and DAM, where low $\mathrm{pH}$ values of $\sim 4.9$ agreed well with previous findings (Bernasconi et al., 2011). Total carbon was dominated by IC at all calcareous sites (7 to $11 \%$ ) and siliceous site TSV $(0.3 \%)$, whereas at other siliceous sites TC and IC were in the same low range (0.01 to $0.08 \%)$. Note that TOC is not reported, as the difference between TC and IC was always in the range of individual sample variability. Elemental contents of $\mathrm{Al}, \mathrm{Fe}$ and $\mathrm{P}$ were significantly lower in calcareous sites; on the contrary, these soils were enriched in $\mathrm{S}$ compared to siliceous sites. Total contents of $\mathrm{Cu}$ showed no dependence on site or bedrock type.

Contents of DOC were generally low at all sites (22 to $78 \mu \mathrm{g}$ (g d.w. $\left.)^{-1}\right)$ and showed no significant correlation with site or bedrock type. Concentrations of mineral nitrogen species $\mathrm{NH}_{4}^{+}$and $\mathrm{NO}_{3}^{-}$were both significantly enriched at calcareous sites, although concentrations were in the lower $\mu$ g (g d.w.) $)^{-1}$ range and close to detection limit. Phosphate was below detection limit $(\sim 0.8 \mu \mathrm{M})$ of our instrument at almost all sites, with the exception of BAR and FOR. In accordance with total $\mathrm{S}$ contents, $\mathrm{SO}_{4}^{2-}$ showed significantly higher concentrations at calcareous sites.

\subsection{Soil $\mathrm{CH}_{4}$ profiles and $\mathrm{CH}_{4}$ fluxes}

Profiles from four selected sites representing typical situations encountered in this survey are plotted in Fig. 1. Graphs of all measured profiles are provided in Supplementary

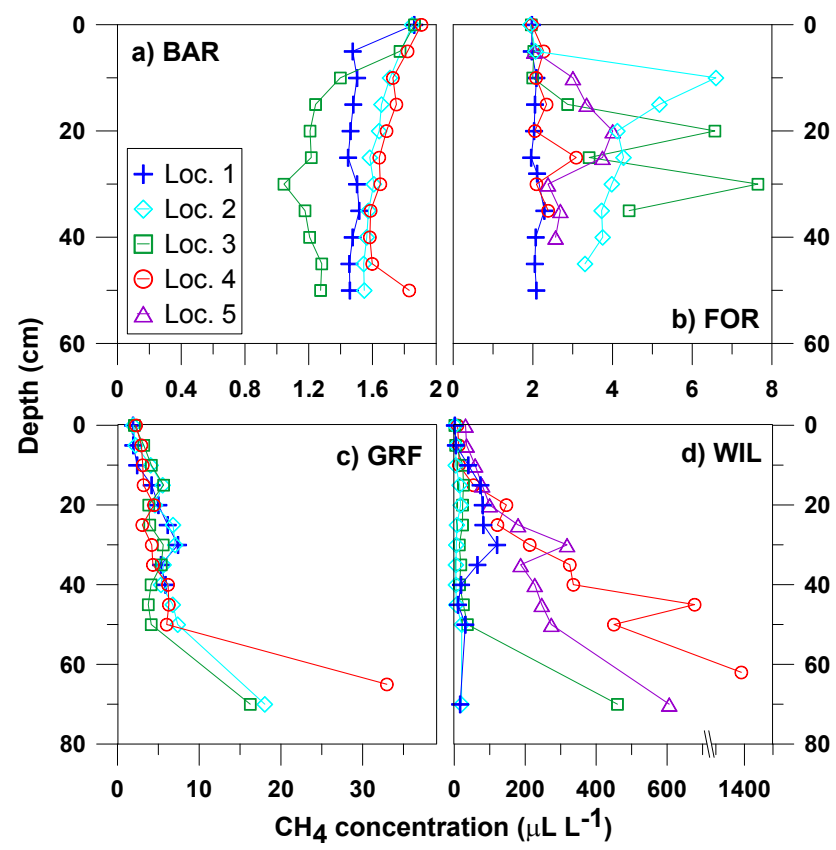

Fig. 1. Selection of measured soil-gas $\mathrm{CH}_{4}$ concentration profiles representative for the different situations encountered. The legend in plot (a) applies to all subplots. Note the different scale in $\mathrm{CH}_{4}$ concentrations for each site.

Fig. S1. At 11 sampled locations in siliceous forefields, soilgas $\mathrm{CH}_{4}$ concentrations decreased with depth and showed a curvature, which indicates consumption of atmospheric $\mathrm{CH}_{4}$ (e.g. BAR 1-4, Fig. 1a). For these locations, lowest measured concentrations ranged between $1.0-1.5 \mu \mathrm{LL}^{-1}$. In 11 other profiles from siliceous sites, $\mathrm{CH}_{4}$ concentrations fluctuated around atmospheric levels (e.g. FOR 1, Fig. 1b). We expect no significant $\mathrm{CH}_{4}$ turnover at these locations, although we cannot fully exclude the possibility that consumption and production balanced out at the micro-scale level. In 37 of the 59 analyzed profiles, measured soil-gas $\mathrm{CH}_{4}$ concentrations clearly exceeded atmospheric $\mathrm{CH}_{4}$ concentrations. At 15 of these locations, all but one (GRF 1) from siliceous sites, highest $\mathrm{CH}_{4}$ concentrations were only slightly elevated, but always $<10 \mu \mathrm{LL}^{-1}$, while lowest concentrations could drop below atmospheric levels (e.g. FOR 2, 4 and 5, Fig. 1b). The remaining 22 locations, all from calcareous sites, exhibited soil-gas $\mathrm{CH}_{4}$ concentrations $>10 \mu \mathrm{LL}^{-1}$, sometimes by orders of magnitude (e.g. GRF and WIL, Fig. 1c and d). Highest concentrations reached 15 to $130 \mu \mathrm{LL}^{-1}$, with the exception of WIL where values up to $1400 \mu \mathrm{LL}^{-1}$ were measured. Profile shapes of most locations clearly indicated a substantial $\mathrm{CH}_{4}$ source below our sampling zone (hereafter referred to as deep-soil $\mathrm{CH}_{4}$ source), coupled with $\mathrm{CH}_{4}$ oxidation in higher soil layers. Note that oxygen concentrations in soil gas from WIL 4 and 5 profiles were close to $20 \mathrm{vol} \%$ at all depths (data not shown). 
Table 2. Overview of physical properties at sampled sites in $0-10 \mathrm{~cm}$ soil depth. Soil texture is reported in sequence of sampled locations; for soil temperature, skeleton content, $\theta_{\mathrm{t}}$ and $\mathrm{S}_{\mathrm{W}}$, we reported the the median with the range of measured values in parentheses. Note that the median should be interpreted with care for sites with a small number of sampled locations (see Table 1).

\begin{tabular}{|c|c|c|c|c|c|c|}
\hline & $\begin{array}{r}\text { Site } \\
\text { abbrev. }\end{array}$ & $\begin{array}{r}\text { Soil temperature } \\
\qquad\left({ }^{\circ} \mathrm{C}\right)\end{array}$ & $\begin{array}{l}\text { Soil texture } \\
(<2 \mathrm{~mm})\end{array}$ & $\begin{array}{r}\text { Skeleton content } \\
(>2 \mathrm{~mm} ; \mathrm{wt} \%)\end{array}$ & Porosity $\theta_{\mathrm{t}}$ & $\begin{array}{r}\text { Water saturation } \\
S_{\mathrm{W}}(\operatorname{vol} \%)\end{array}$ \\
\hline \multirow{8}{*}{ 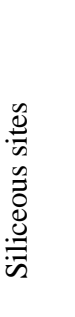 } & BAR & $10(9-13)$ & $\mathrm{s}, \mathrm{s}, \mathrm{ls}, \mathrm{s}$ & $27(10-59)$ & $0.43(0.39-0.52)$ & $20(15-26)$ \\
\hline & DAM & $6(4-10)$ & $\mathrm{s}, \mathrm{s}, \mathrm{s}, \mathrm{s}$ & n.a. & $0.43(0.38-0.45)$ & $9(7-16)$ \\
\hline & FOR & $11(8-15)$ & sil, s, s, s, s & $6(2-21)$ & $0.54(0.46-0.59)$ & $22(2-37)^{\mathrm{c}}$ \\
\hline & MOM & $16(15-21)$ & ls, sl, sl, sl & $27(2-36)$ & $0.40(0.39-0.50)$ & $29(18-34)$ \\
\hline & MRT & $16(8-22)$ & $\mathrm{s}, \mathrm{s}, \mathrm{s}, \mathrm{s}, \mathrm{s}, \mathrm{s}, \mathrm{ls}$ & $3(1-16)$ & $0.49(0.36-0.57)$ & $11(2-28)^{\mathrm{c}}$ \\
\hline & STI & $12(7-17)$ & $\mathrm{s}, \mathrm{s}, \mathrm{s}, \mathrm{s}$ & n.a. & $0.50^{\mathrm{c}, \mathrm{d}}$ & $20^{\mathrm{d}}$ \\
\hline & STL & $23(20-26)$ & $\mathrm{s}, \mathrm{s}, \mathrm{s}, \mathrm{s}$ & $30(6-38)$ & $0.46(0.40-0.48)$ & $12(7-60)$ \\
\hline & TSV & $16(15-16)$ & ls, ls, sl, s & $21(14-45)$ & $0.47(0.41-0.49)$ & $6(4-17)^{\mathrm{c}}$ \\
\hline \multirow{5}{*}{ 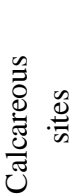 } & CLF & $12(11-14)$ & 1s, s, s & $17(17-69)$ & $0.46(0.46-0.49)$ & $11(1-11)^{\mathrm{c}}$ \\
\hline & GRF & $16(14-16)$ & $\mathrm{s}, \mathrm{s}, \mathrm{s}, \mathrm{s}$ & $38(18-60)$ & $0.42(0.36-0.45)$ & $13(9-17)$ \\
\hline & GRI & $13(8-16)$ & $1, \mathrm{sl}, 1, \mathrm{sl}, \mathrm{s}$ & 76(41-95) & $0.38(0.36-0.51)$ & $20(14-35)$ \\
\hline & KLG & $18(17-20)$ & $\mathrm{s}, \mathrm{s}, \mathrm{s}, \mathrm{s}, \mathrm{s}, \mathrm{ls}$ & $13(2-77)$ & $0.51(0.42-0.57)$ & $10(5-23)$ \\
\hline & WIL & $15(12-16)$ & $\mathrm{s}, \mathrm{ls}, \mathrm{ls}, \mathrm{s}, \mathrm{s}$ & $62(47-62)$ & $0.43(0.37-0.46)$ & $13(8-23)$ \\
\hline
\end{tabular}

\footnotetext{
a Soil temperatures $(0-10 \mathrm{~cm})$ measured at the actual time of sampling.

${ }^{b}$ s = sand; ls = loamy sand; sl = sandy loam; $1=$ loam; sil = silty loam.

${ }^{\mathrm{c}}$ Measurements of volumetric water content by TDR.

d Data for location 4 only; no data available for location 1-3 n.a. not available.
}

Table 3. Site mean of measured chemical parameters for each glacier forefield. Values are reported with \pm 2 sd, which reflects the variance within the site. Organic carbon is not reported, as the difference between TC and IC was below the sd of individual sample replicates.

\begin{tabular}{|c|c|c|c|c|c|c|c|c|c|c|c|c|c|c|c|c|}
\hline & \multirow{2}{*}{$\begin{array}{c}\text { Site } \\
\text { abbrev. }\end{array}$} & \multirow[b]{2}{*}{$\mathrm{pH}$} & $\mathrm{A} 1$ & $\mathrm{Si}$ & $\mathrm{Ca}$ & $\mathrm{Fe}$ & \multirow{2}{*}{$\begin{array}{c}\mathrm{P} \\
\mathrm{mg}(\mathrm{g} \mathrm{d.w.})^{-1}\end{array}$} & $\mathrm{~S}$ & $\mathrm{Cu}$ & \multirow{2}{*}{$\begin{array}{l}\mathrm{TC} \\
\%\end{array}$} & \multirow{2}{*}{$\begin{array}{l}\mathrm{IC} \\
\%\end{array}$} & DOC & $\mathrm{NH}_{4}^{+}$ & $\mathrm{NO}_{3}^{-}$ & $\mathrm{PO}_{4}^{3-}$ & $\mathrm{SO}_{4}^{2-}$ \\
\hline & & & \multicolumn{4}{|c|}{$\%$} & & \multicolumn{2}{|c|}{$\mu \mathrm{g}(\mathrm{g} \text { d.w. })^{-1}$} & & & \multicolumn{5}{|c|}{$\mu \mathrm{g}(\mathrm{gd} \text { d.w. })^{-1}$} \\
\hline \multirow{16}{*}{ 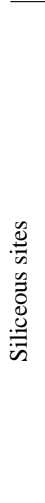 } & & 6.42 & 5.31 & 22.1 & 1.95 & 2.56 & 0.398 & & 6.80 & 0.035 & 0.016 & 30.0 & 0.313 & 0.138 & 0.639 & \\
\hline & BAR & \pm 0.51 & \pm 0.85 & \pm 3.5 & \pm 0.35 & \pm 0.57 & \pm 0.094 & $<2$ & \pm 3.3 & \pm 0.016 & \pm 0.020 & \pm 6.0 & \pm 0.55 & \pm 0.15 & \pm 0.90 & $<1.77$ \\
\hline & & 4.88 & 4.06 & 22.6 & 0.53 & 0.87 & 2.15 & & 1.75 & 0.021 & & 70.6 & & & & \\
\hline & DAM & \pm 0.090 & \pm 1.2 & \pm 1.5 & \pm 0.070 & \pm 0.10 & \pm 0.079 & & \pm 1.3 & \pm 0.028 & n.d & \pm 24 & $=0.17$ & 0.13 & n.d. & $<1.77$ \\
\hline & & 7.24 & 4.52 & 19.6 & 2.20 & 1.71 & 1.02 & & 5.24 & 0.083 & 0.044 & 33.0 & 0.194 & 0.136 & 0.537 & \\
\hline & FOR & \pm 0.66 & \pm 1.2 & \pm 3.6 & \pm 1.1 & \pm 1.0 & \pm 1.3 & $<20$ & \pm 4.1 & \pm 0.075 & \pm 0.092 & \pm 34 & \pm 0.095 & \pm 0.22 & \pm 1.5 & $<1.77$ \\
\hline & & 7.91 & 5.01 & 22.8 & 1.75 & 1.90 & 0.266 & 34.9 & 7.03 & 0.033 & 0.018 & 32.6 & & 0.214 & 2.83 & 4.88 \\
\hline & MOM & \pm 1.1 & \pm 0.14 & \pm 0.88 & \pm 0.22 & \pm 0.31 & \pm 0.046 & \pm 41 & \pm 3.4 & \pm 0.023 & \pm 0.032 & \pm 7.5 & $<0.17$ & \pm 0.23 & n.a. & \pm 4.4 \\
\hline & & 6.22 & 4.36 & 21.8 & 1.28 & 2.06 & 0.362 & & 5.94 & 0.026 & & 34.6 & & 0.183 & 1.06 & 2.20 \\
\hline & MR' & \pm 1.4 & \pm 1.1 & \pm 6.2 & \pm 1.4 & \pm 2.0 & \pm 0.39 & $<2$ & \pm 3.1 & \pm 0.022 & $<0.0$ & \pm 35 & $<0.17$ & \pm 0.19 & \pm 2.0 & \pm 2.2 \\
\hline & & 7.26 & 5.11 & 22.2 & 1.18 & 2.60 & 0.061 & & 21.9 & 0.071 & 00 & 23.8 & 0 & 0.166 & $n d$ & 6.90 \\
\hline & S11 & n.a. & n.a. & n.a. & n.a. & n.a. & n.a. & & n.a. & n.a. & 00 & n.a. & 7 & n.a. & n.d. & n.a. \\
\hline & & 6.36 & 4.38 & 18.2 & 0.88 & 2.29 & 0.594 & & 11.3 & 0.020 & 0.064 & 44.7 & & 0.154 & & 3.99 \\
\hline & STL & \pm 0.97 & \pm 1.0 & \pm 3.8 & \pm 0.31 & \pm 0.19 & \pm 0.094 & & \pm 4.8 & \pm 0.011 & \pm 0.18 & \pm 42 & & \pm 0.31 & n.d. & \pm 5.5 \\
\hline & TSV & 8.33 & 5.17 & 22.2 & 3.18 & 2.75 & 0.619 & 2 & 10.5 & 0.298 & 0.316 & 38.4 & 7 & 0.184 & d & 1.87 \\
\hline & 1SV & \pm 0.22 & \pm 0.37 & \pm 1.03 & \pm 0.83 & \pm 0.28 & \pm 0.17 & & \pm 2.4 & \pm 0.14 & \pm 0.13 & \pm 36 & 7 & \pm 0.37 & n.d. & \pm 1.0 \\
\hline \multirow{10}{*}{ 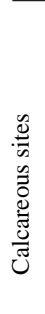 } & & 8.02 & 1.66 & 8.11 & 24.9 & 1.90 & 0.211 & 51.9 & 7.23 & 7.61 & 7.43 & 77.6 & 0.717 & 0.248 & & 4.30 \\
\hline & CLF & \pm 0.29 & \pm 0.21 & \pm 1.9 & \pm 3.5 & \pm 0.32 & \pm 0.095 & \pm 34 & \pm 1.5 & \pm 1.3 & \pm 1.1 & \pm 24 & \pm 0.51 & \pm 0.20 & n.d. & \pm 9.2 \\
\hline & & 8.36 & 3.12 & 10.4 & 20.0 & 2.52 & 0.161 & 425 & 18.7 & 6.67 & 6.45 & 70.1 & 0.551 & 1.31 & & 11.1 \\
\hline & GRF & \pm 0.15 & \pm 1.4 & \pm 2.6 & \pm 5.0 & \pm 0.75 & \pm 0.063 & \pm 410 & \pm 13 & \pm 2.1 & \pm 1.9 & \pm 5.0 & \pm 0.29 & \pm 1.7 & n.d. & \pm 13 \\
\hline & GRI & 8.64 & 0.410 & 1.52 & 36.2 & 0.430 & 0.100 & 117 & 4.70 & 11.4 & 11.2 & 32.7 & 0.440 & 0.262 & & 3.51 \\
\hline & GRI & \pm 0.18 & \pm 0.13 & \pm 1.1 & \pm 2.9 & \pm 0.32 & \pm 0.031 & \pm 30 & \pm 1.5 & \pm 0.66 & \pm 0.95 & \pm 34 & \pm 0.50 & \pm 0.20 & $<0.20$ & \pm 5.8 \\
\hline & KIG & 8.26 & 2.11 & 7.94 & 25.2 & 1.90 & 0.144 & 136 & 10.3 & 7.84 & 7.68 & 22.2 & 0.690 & 0.707 & 2.76 & 13.7 \\
\hline & KLG & \pm 0.20 & \pm 0.67 & \pm 1.6 & \pm 3.4 & \pm 0.38 & \pm 0.048 & \pm 89 & \pm 2.9 & \pm 1.2 & \pm 1.3 & \pm 1.9 & \pm 0.45 & \pm 0.89 & n.a. & \pm 18 \\
\hline & & 8.55 & 1.54 & 9.80 & 26.5 & 1.03 & 0.0917 & 156 & 5.44 & 8.19 & 8.17 & 64.7 & 0.272 & 0.391 & & 4.65 \\
\hline & WIL & \pm 0.36 & \pm 1.5 & \pm 1.1 & \pm 3.4 & \pm 0.73 & \pm 0.085 & \pm 88 & \pm 3.3 & \pm 0.78 & \pm 0.81 & \pm 20 & \pm 0.20 & \pm 0.14 & n.d. & \pm 1.7 \\
\hline
\end{tabular}

n.d.: not detected; n.a.: not available 


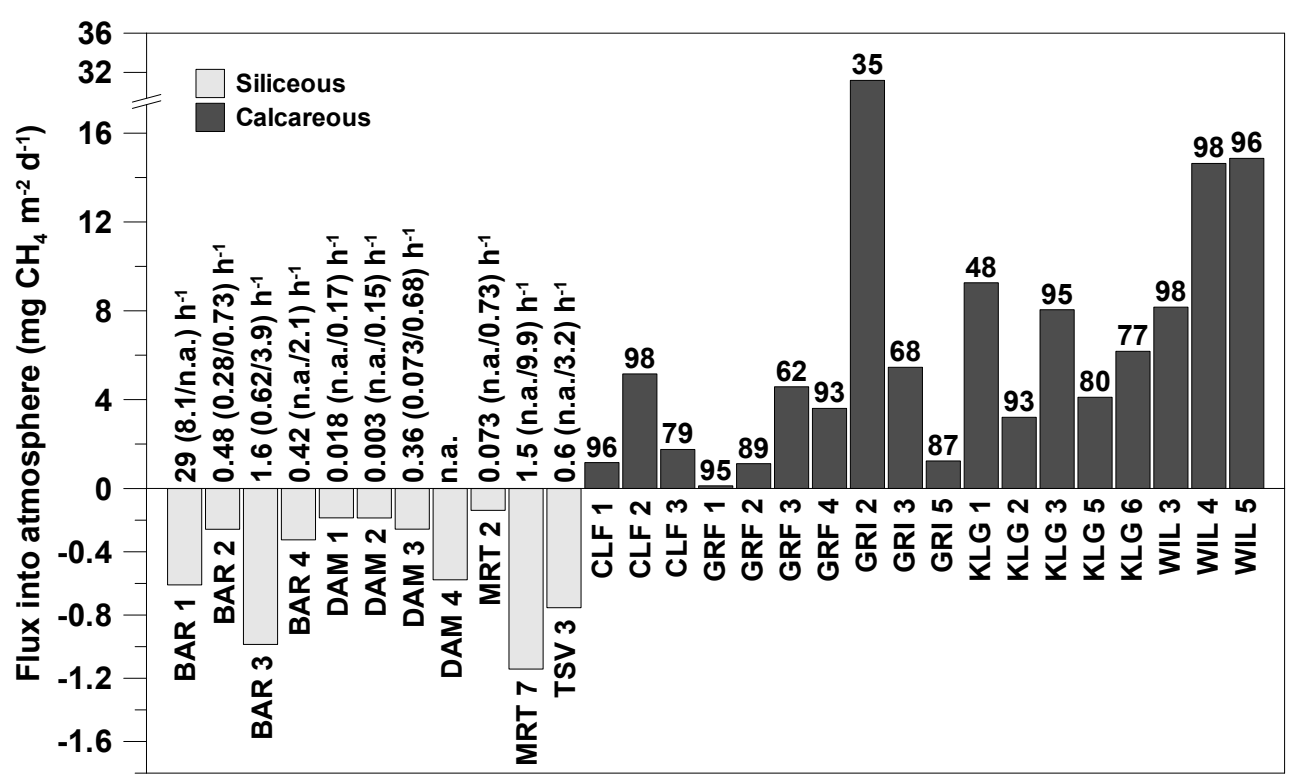

Fig. 2. Fluxes of $\mathrm{CH}_{4}$ from the soil into the atmosphere $\left(J_{\mathrm{atm}}\right)$ for locations where the profile shape allowed quantification. Negative $J_{\text {atm }}$ indicate that the soil was a sink for atmospheric $\mathrm{CH}_{4}$. For these locations estimated $k$ of $\mathrm{CH}_{4}$ oxidation are reported (with low/high $95 \%$ confidence interval). For locations with positive $J_{\mathrm{atm}}$, the number above the bars indicates the percentage of $\mathrm{CH}_{4}$ oxidized in the soil before reaching the atmosphere. Note that the scale for negative and positive fluxes is different.

Table 4. Number of samples with successful amplification using different primer combinations during normal (first round) and nested (second round) PCR reactions. The second-round PCR was performed with the product of the first-round primer set A189fA682r. Total number of samples selected for molecular analyses was 27.

\begin{tabular}{llrrr}
\hline \multirow{2}{*}{$\begin{array}{l}\text { PCR } \\
\text { reaction }\end{array}$} & Forward & \multicolumn{3}{c}{ Reverse primer } \\
\cline { 3 - 5 } frimer & A682r & mb661r & A650r \\
\hline \multirow{2}{*}{ first round } & A189f & 17 & 1 & 0 \\
\hline \multirow{2}{*}{ second round } & A189f & & 0 & 0 \\
& pmoA206f & & 27 & 0 \\
\hline
\end{tabular}

For the 11 profiles exhibiting atmospheric $\mathrm{CH}_{4}$ consumption, estimated (negative) $J_{\text {atm }}$ ranged from -0.14 to $1.1 \mathrm{mg} \mathrm{m}^{-2} \mathrm{~d}^{-1}$, while $k$ ranged from 0.003 to $29 \mathrm{~h}^{-1}$, with large uncertainties associated with smallest and largest $k$ (Fig. 2). All 18 profiles indicating a deep-soil $\mathrm{CH}_{4}$ source were net $\mathrm{CH}_{4}$ emitters, and $J_{\text {atm }}$ ranged from 0.12 to $31 \mathrm{mg} \mathrm{m}^{-2} \mathrm{~d}^{-1}$, with a mean of $6.9 \mathrm{mg} \mathrm{m}^{-2} \mathrm{~d}^{-1}$. Half of the soils oxidized more than $90 \%$ of the $\mathrm{CH}_{4}$ before it could reach the atmosphere (Fig. 2). Sink strength of $\mathrm{CH}_{4}$ oxidation, i.e. the difference between $J_{\mathrm{ds}}$ and $J_{\mathrm{atm}}$, was in the range of 2.5 to $240 \mathrm{mg} \mathrm{m}^{-2} \mathrm{~d}^{-1}$, except for WIL 3-5, where the sink was in the range of 350 to $700 \mathrm{mg} \mathrm{m}^{-2} \mathrm{~d}^{-1}$.

\section{3 pmoA presence and diversity analysis}

The procedure recommended by the manufacturer (MP Biomedicals) for DNA extraction did not yield a sufficient amount of total DNA from most of our samples. DNA in sufficient yield and purity was, however, consistently obtained after we replaced the protein precipitation step by a proteinase K treatment. PCR of bacterial 16S rRNA genes gave strong products of correct size for all the DNA extracts. For initial detection of pmoA, we tested 27 DNA extracts with the forward primer A189f in combination with various reverse primers (A650r, mb661r, and A682r). None of the primer combinations consistently produced pmoA amplicons from all extracts, but the use of the primer set A189fA682r resulted in detectable amplicons from 17 samples (Table 4). Nested PCR (with the product of the primer set A189fA682r) using forward primer A189f in the second round failed, regardless of whether it was combined with A650r or mb661r. However, replacement with pmoA206f (a variant of A189f with 17 additional bases added to its 3' end) consistently produced detectable $p m o A$ amplicons from all the 27 DNA extracts using reverse primer mb661 (Table 4). The combination pmoA206f-A650r again produced no amplicons. Therefore, for cloning, sequencing and T-RFLP analysis, we used primarily pmoA amplicons generated in nested PCR with pmoA206f-mb661 in second-round PCR (27 samples representing all 13 sites). First-round PCR amplicons from primers A189f-682r (17 samples from 10 sites) were used for validation of results. 


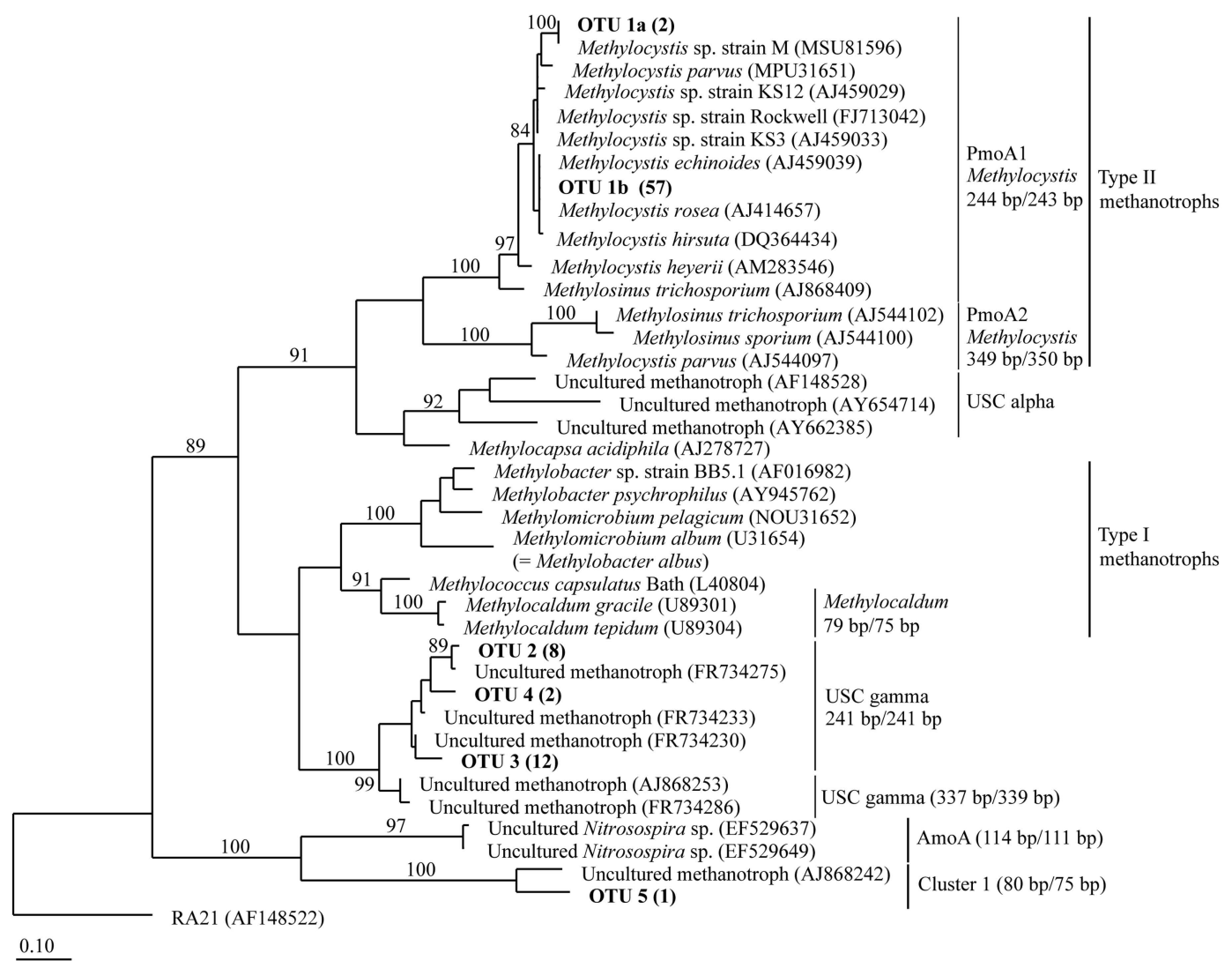

Fig. 3. Maximum likelihood tree showing the phylogenetic affiliation of $p m o A$ sequences obtained from different glacier forefields. The pmoA tree was constructed based on 139 derived amino acid sequence positions. The neighbor-joining method resulted in essentially the same tree topology. Sequences obtained in the course of this study were grouped into 5 species-level units (OTU 1 to 5) based on an amino acid sequence identity threshold of $93 \%$. The number of clones obtained for each OTU is given in parentheses. All species-level OTUs also contain published $p m o A$ sequences. Predicted T-RF lengths based on MspI are shown on the left side, while the experimental T-RF lengths are indicated on the right side. The in silico predicted T-RF lengths were experimentally confirmed by T-RFLP analysis of individual pmoA clone sequences. Bootstrap values greater than 80 are shown (100 replicates). The sequence of RA21 (AF148522) was used as outgroup. The scale bar represents $10 \%$ sequence divergence or 0.1 substitutions per amino acid position.

Of the 82 pmoA clones randomly selected for analysis, 59 clone sequences were assigned to the pmoAl of Methylocystis, while 22 pmoA sequences belonged to USC $\gamma$. These 81 pmoA clone sequences were used to define four species-level operational taxonomic units (OTU-1 to OTU-4) based on $7 \%$ divergence of deduced amino acid sequences (Fig. 3). The Methylocystis-like OTU was separated into two subgroups (OTU1a, 1b). The pmoAl clone sequences of OTU1a are most similar to that of Methylocystis sp. M (derived amino acid sequence identity of $98.9 \%$ ), and those of the OTU1b (the vast majority) share greatest identity with $p m o A l$ of Methylocystis sp. strain Rockwell (ATCC 49242; 98.9\%). The three USC $\gamma$-like OTUs 2, 3, and 4 are distinct from each other, with sequence identity values of $92 \%$ at the amino acid level. Each is most closely related to $p m o A$ sequences retrieved from an alpine meadow soil. The single $p m o A$ sequence of OTU5 is most closely related to a Cluster I pmoA sequence that was detected in deciduous forest soil.
The T-RFLP patterns obtained from all 27 samples by nested PCR can be grouped into two distinct sets of profiles that are dominated by either a 241-bp T-RF or a 243-bp T-RF (Fig. 4). Comparative analysis of $p m o A$ clones assigned the 241-bp T-RF to USC $\gamma$, while the 243-bp T-RF was highly characteristic of the pmoAl of Methylocystis (Fig. 3). These assignments were consistently confirmed by in silico analysis of all the 81 pmoA clones that had been assigned to either Methylocystis or USC $\gamma$. The USC $\gamma$-related 241-bp TRF dominated most T-RFLP patterns, including all samples from siliceous sites (Fig. 4). A few T-RFLP patterns (MRT 7, GRI 2, KLG 3 and KLG 4) showed the presence of both the 241-bp and 243-bp T-RFs, with the 241-bp T-RF being always the dominant fragment. The Methylocystis-related 243bp T-RF dominated only in four T-RFLP patterns (GRF 1, GRF 2, WIL 1 and WIL 5), all obtained from calcareous sites. 


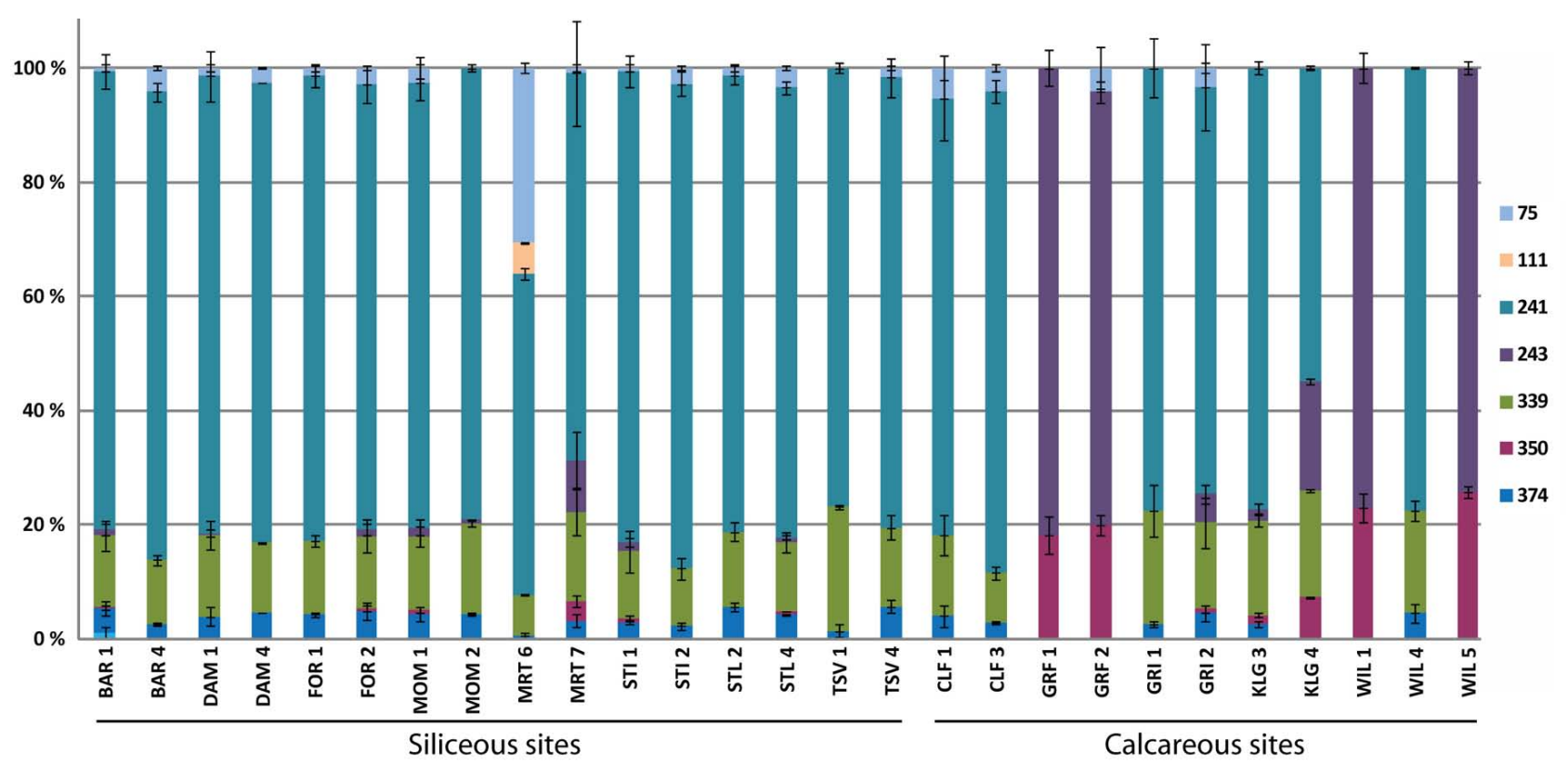

Fig. 4. Bar diagrams of $p m o A$-based T-RFLP fingerprint patterns obtained from all 27 subsamples representing the 13 different glacier forefields. The T-RFLP patterns were generated using the primer set A189f-A682r in first-round PCR and the primer set pmoA206f-mb661 in nested second-round PCR. The percentage abundances (mean $\pm s d ; n=3$ ) of 7 distinguishable T-RFs are indicated by different colors.

Besides the dominant 241-bp and 243-bp T-RFs, the TRFLP profiles showed the presence of two additional T-RFs with a size of 339 and $350 \mathrm{bp}$. No pmoA clone sequences affiliated with these two T-RFs could be obtained. However, in computational analysis using a manually curated database, the 339-bp T-RF was affiliated with pmoA of a particular USC $\gamma$ population, while the 350-bp T-RF appears to represent pmoA2 of the Methylocystis/Methylosinus group. These in silico assignments are supported by the consistent cooccurrence of the 241-bp and 339-bp T-RFs and, on the other hand, the 243-bp and 350-bp T-RFs in the T-RFLP patterns (Fig. 4). As suggested by a single pmoA clone obtained from sample MRT 7, the 75-bp T-RF found mainly in MRT 6 may represent members of the $p m o A$ Cluster 1. The T-RFLP patterns generated from 17 samples by first-round PCR with primer set A189f-682r confirmed the dominant presence of either the combination of the 241-bp and 339-bp T-RFs, or the 243-bp T-RF (Supplement Fig. S2).

\section{Discussion}

\subsection{Soil properties}

Physical properties of the sampled soils varied over a wide range (Table 2), as would be expected from soils in their initial development stage (Egli et al., 2006). However, properties showed no obvious dependence on site characteristics, including bedrock type. The majority of soils had a high porosity, and $S_{\mathrm{w}}$ was low, as we sampled in dry weather and during the warmest period of the year. Hence, our estimates for $D_{\text {eff }}$, and therefore both $J_{\text {atm }}$ and $J_{\mathrm{ds}}$, are most likely at the higher end of values that could be expected for glacier forefields.

In general, concentrations of nutrients such as $\mathrm{P}, \mathrm{N}$, and DOC were low in glacier forefield soils irrespective of bedrock type (Table 3; Lazzaro et al., 2009 and 2011; Bernasconi et al., 2011). Conversely, chemical parameters including $\mathrm{pH}$, total $\mathrm{Si}, \mathrm{Ca}, \mathrm{Al}, \mathrm{Fe}, \mathrm{S}$, and IC depended on geology and were significantly different between bedrock types. As expected for calcareous sites consisting mainly of limestone $\left(\mathrm{CaCO}_{3}\right)$ and being low in organic carbon, high $\mathrm{TC}$ was comprised mainly of IC. Notably, IC and Ca values at individual calcareous sites agreed exceptionally well with each other when taking into account the species' $1: 1$ stoichiometry in $\mathrm{CaCO}_{3}$ (computations not shown). We tested selected parameters within each bedrock type for correlations with $\mathrm{CH}_{4}$ turnover and MOB diversity, and discuss them in respective sections below.

\subsection{Soil- $\mathrm{CH}_{4}$ profile categorization}

Our initial expectation was that most soils would show $\mathrm{CH}_{4}$ concentrations slightly below atmospheric levels as a result of atmospheric $\mathrm{CH}_{4}$ oxidation, with some rare exceptions of slight concentration increases resulting from microsite methanogenesis. Surprisingly, almost two thirds of all measured profiles showed elevated $\mathrm{CH}_{4}$ concentrations, and around one third of all profiles indicated a substantial deep-soil $\mathrm{CH}_{4}$ source. To provide an overview of the 


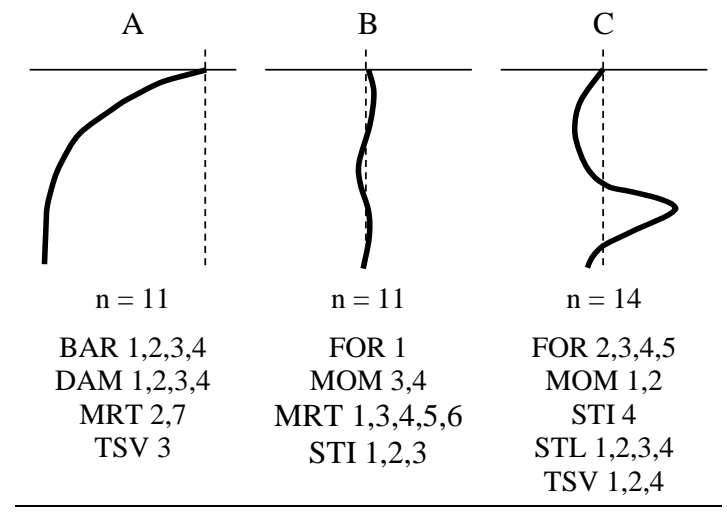

Highest soil- $\mathrm{CH}_{4}$ conc. $<10 \mu \mathrm{L} \mathrm{L}^{-1}$;

All assigned profiles originate from siliceous sites

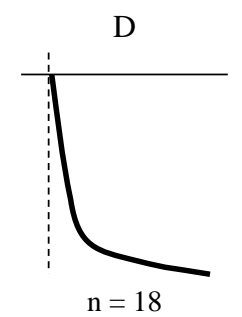

CLF $1,2,3$

GRF 1 a $, 2,3,4$

GRI $2,3,5$

KLG 1,2,3,5,6

WIL $3,4,5$

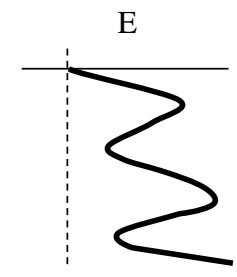

$\mathrm{n}=5$

GRI 1,4

KLG 4

WIL 1,2

Highest soil- $\mathrm{CH}_{4}$ conc. $>10 \mu \mathrm{L} \mathrm{L}^{-1}$;

All assigned profiles originate from calcareous sites

${ }^{\text {a }}$ Soil- $\mathrm{CH}_{4}$ conc. were $<10 \mu \mathrm{L} \mathrm{L}^{-1}$, but congruent with close-by GRF 2 down to deepest possible sampling point $(40 \mathrm{~cm})$.

Fig. 5. Qualitative categories A-E assigned to measured soil-gas $\mathrm{CH}_{4}$ profiles according to profile appearance. Illustrated profile shapes are typical for each category. The vertical line indicates atmospheric $\mathrm{CH}_{4}$ concentration. Sampled locations assigned to the respective categories are listed below.

distribution of dominating processes, we therefore assigned each measured profile to a category according to the generalized shape of the profile (Fig. 5). We distinguished five profile categories that featured the following dominating processes: (A) oxidation of atmospheric $\mathrm{CH}_{4}$; (B) no apparent $\mathrm{CH}_{4}$ turnover; (C) small production of $\mathrm{CH}_{4}$ in anoxic microsites $\left(\mathrm{CH}_{4}\right.$ conc. $<10 \mu \mathrm{LL}^{-1}$; limit for growth of cultured oligotrophic MOB; Knief and Dunfield, 2005); (D) substantial deep-soil $\mathrm{CH}_{4}$ source $\left(>10 \mu \mathrm{L} \mathrm{L}^{-1}\right)$ and $\mathrm{CH}_{4}$ oxidation in the topsoil; (E) substantial $\mathrm{CH}_{4}$ source $\left(>10 \mu \mathrm{LL}^{-1}\right)$ but undefined profile shape (zig-zag). All profiles from siliceous sites fell into categories A, B and C, while all profiles from calcareous sites featured a substantial deep-soil $\mathrm{CH}_{4}$ source and fell into categories D and E. Given this clear distinction, we discuss the two bedrock types separately below.

Errors in concentration gradients were most likely dominated by local soil heterogeneity, but as no replicate profiles could be taken due to the destructive sampling procedure, we cannot estimate their magnitude. However, having collected several profiles in close proximity, we are confident that our results reflect the general conditions in situ and provide a first estimate of the magnitude of $\mathrm{CH}_{4}$ turnover in Swiss glacier forefields.

\subsubsection{Methane turnover and fluxes at siliceous sites}

Considering only siliceous sites, our results support our initial hypothesis of low atmospheric $\mathrm{CH}_{4}$ consumption (cat. A) and limited but prevalent methanogenesis in anoxic microsites (cat. C). Bárcena et al. (2010) recently investigated $\mathrm{CH}_{4}$ oxidation in a (siliceous) glacier forefield in Greenland and found uptake of atmospheric $\mathrm{CH}_{4}$ in 7 of their 12 sites, with one site at the glacier front emitting $\mathrm{CH}_{4}$. However, our $J_{\text {atm }}$ values were two orders of magnitude higher than their values $\left(-0.0034\right.$ to $\left.-0.018 \mathrm{mg} \mathrm{m}^{-2} \mathrm{~d}^{-1}\right)$, and compared best with the lower end of estimates from cold and temperate ecosystems obtained with similar methods (Born et al., 1990: 0.25-3.4 $\mathrm{mg} \mathrm{m}^{-2} \mathrm{~d}^{-1}$; Whalen et al., 1992: 0.77$1.78 \mathrm{mg} \mathrm{m}^{-2} \mathrm{~d}^{-1}$ ). Direct comparability with chamber-based net $\mathrm{CH}_{4}$ fluxes such as reported by Bárcena et al. is limited, as $\mathrm{CH}_{4}$ consumption could have been confounded by microsite methanogenesis (Andersen et al., 1998; Kammann et al., 2001 and 2009). In glacier forefields, a possible carbon source for methanogenesis might be subfossil wood and peat from glacier-buried vegetation (Hormes et al., 2001). For example, compressed peat disks recovered from the FOR forefield and described in Joerin et al. (2006) could be the origin of localized anoxic conditions due to increased heterotrophic activity at the peat surface.

Profile categories A, B and C did not significantly differ in $S_{\mathrm{w}}$ but seemed to be temperature-dependent, i.e. temperatures at locations in cat. A were significantly lower than in cat. B and C (p-value $=0.025)$. Similarly, average soil- $\mathrm{CH}_{4}$ concentrations of "siliceous" profiles were positively correlated with temperature ( $\mathrm{p}$-value $=0.0004 ; R^{2}=0.35$ ). Highaffinity MOB have low temperature sensitivity $\left(\mathrm{Q}_{10} \sim 1-2\right.$; Dunfield et al., 1993; Dunfield, 2007), while methanogens show much higher sensitivity $\left(\mathrm{Q}_{10} \sim 5-16\right.$; Dunfield et al., 1993; Le Mer and Roger, 2001). Possibly, a rather stable activity of MOB might be confounded by increasing methanogenesis at higher temperatures. Soil $\mathrm{pH}$ was the only other factor showing a correlation with profile categories, i.e. locations in cat. A exhibited significantly lower $\mathrm{pH}$ values ( $\mathrm{p}$ value $=0.002$ ). Methanogens and MOB occur over wide pH ranges (e.g. Le Mer and Roger, 2001), but it might be 
possible that they have different resilience to a gradual decrease in $\mathrm{pH}$ occurring during soil development in siliceous glacier forefields (Bernasconi et al., 2011).

\subsubsection{Methane turnover and fluxes at calcareous sites}

Detection of substantial soil- $\mathrm{CH}_{4}$ sources at all sampled locations in calcareous glacier forefields was unexpected, as was the magnitude of associated fluxes. At the time of sampling, all soils from calcareous sites appeared to be net $\mathrm{CH}_{4}$ emitters. The range of $J_{\text {atm }}$ from locations of cat. D compared best with temporarily submerged upland soils (Wang and Bettany, 1997: 7.8-10.5 $\mathrm{mg} \mathrm{m}^{-2} \mathrm{~d}^{-1}$ ) and the lower end of estimates from peat bog environments (e.g. Moore and Knowles, 1990: $\sim 5 \mathrm{mg} \mathrm{m}^{-2} \mathrm{~d}^{-1}$; Fechner and Hemond, 1992: 3.5-51 $\mathrm{mg} \mathrm{m}^{-2} \mathrm{~d}^{-1}$; Le Mer and Roger, 2001: $43.3 \mathrm{mg} \mathrm{m}^{-2} \mathrm{~d}^{-1}$ (median of 4 sources)). Half of the soils of cat. D oxidized more than $90 \%$ of $J_{\mathrm{ds}}$, a magnitude usually found in landfill cover soils (De Visscher et al., 2007). This would imply a substantial population of MOB in the most active zone with highest $\mathrm{CH}_{4}$ turnover, located at $\sim 50-70 \mathrm{~cm}$ depth in most profiles. Unfortunately, our soil sampling depth of $\sim 3-10 \mathrm{~cm}$ did not cover this zone; this will be a subject of future investigations.

The nature of the substantial $\mathrm{CH}_{4}$ source in calcareous glacier forefields remains unknown. Glacially overridden vegetation might directly or indirectly (through relatively labile DOC of subglacial origin; Lafrenière and Sharp, 2004) serve as carbon source for biogenic $\mathrm{CH}_{4}$ production. Alternatively, cryoconite holes on glacier surfaces have been suggested as relevant sources of organic carbon in glacial ecosystems (e.g., Sawstrom et al., 2002; Hodson et al., 2010; Stibal et al., 2010). In both siliceous and calcareous forefields, it is possible that basal ice or permafrost below the vadose zone (note that permafrost is unlikely to exist at our sampling sites; Maisch et al., 2000) might impede drainage and create near-saturated layers that could turn anoxic (Hinkel et al., 2001). However, only on calcareous bedrock can a significant loss in soil porosity occur due to calcite precipitating during freezing (Lacelle, 2007). This could enhance anoxia, and hence methanogenesis.

Alternatively, the sedimentary origin of the calcareous bedrock would also permit a deep geological $\mathrm{CH}_{4}$ source. Thermogenic $\mathrm{CH}_{4}$ formed from trapped organic matter might migrate upwards through faults and fractures and result in emission over wide areas ("microseepage"; Matthews, 1996; Etiope and Klusman, 2002). Interestingly, positive microseepage fluxes reported by Klusman et al. (up to $43 \mathrm{mg} \mathrm{CH}_{4} \mathrm{~m}^{-2} \mathrm{~d}^{-1}$ at the soil-atmosphere boundary; Klusman et al., 2000) were in the same order of magnitude as our positive $J_{\text {atm }}$. To shed light on the origin of the $\mathrm{CH}_{4}$ source, we will focus on the determination of the isotopic composition of soil- $\mathrm{CH}_{4}$ in future work.

From the different parameters tested, only soil temperature showed a correlation with profile categories: tempera- tures were higher at locations in cat. D compared to cat. $\mathrm{E}$ ( $\mathrm{p}$-value $=0.0096)$. However, measured topsoil temperatures bear little informational value for deep-soil processes. Hence, we cannot provide a meaningful interpretation here.

\section{3 pmoA presence and diversity of MOB in Swiss glacier forefields}

After an initial survey of different primer combinations and PCR conditions, we were able to amplify $p m o A$ fragments from all 27 samples and hence confirm the presence of MOB in the 13 glacier forefields studied. The key for consistent detection was a nested PCR approach and the use of the forward primer pmoA206f, originally designed to specifically target pmoA2 (Tchawa Yimga et al., 2003). The pmoA sequences detected in our samples shared sufficient sequence similarity with pmoA206f to be efficiently amplified by the nested PCR approach. Contrary to a study on MOB diversity in glacier forefields in southeast Greenland (Bàrcena et al., 2011), PCR using the primer pair A189f-A650R was unsuccessful. This primer pair favors the detection of USC $\alpha$-like populations. Apparently, the glacier forefields studied here and in southeast Greenland are dominated by different MOB communities.

All but one of the pmoA sequences were associated with either Methylocystis- or USC $\gamma$-like MOB, resulting in a total of only five species-level OTUs. A difference of $7 \%$ between deduced amino acid sequences of $p m o A$ corresponds to $13 \%$ difference in their nucleotide sequences for known methanotrophs (Degelmann et al., 2010; Shrestha et al., 2011; Zheng et al., 2011) and correlates with the species-level distance cutoff value of $3 \%$ based on the 16S rRNA gene (Degelmann et al., 2010). Sequence analysis of an increasing number of pmoA clones may have resulted in the detection of additional species-level diversity within, for example, USC $\gamma$. Nonetheless, it is notable that all the $22 \mathrm{USC} \gamma$-like $p m o A$ sequences belonged to only three species-level OTUs (Fig. 3) and each of these three OTUs was composed of $p m o A$ clones from at least two geographically different sampling sites. This finding suggests that the Swiss glacier forefields may be colonized by a few dominant MOB species. It might be a consequence of the young age of the soils, lack of vegetation and the harsh environmental conditions (e.g. high altitude with strong UV radiation and large temperature shifts) selecting for a few highly specialized MOB.

Although Methylocystis was frequently found in environments with low or atmospheric $\mathrm{CH}_{4}$ concentrations, USC $\gamma$ has rarely been identified (Knief et al., 2003; Knief et al., 2006; Zheng et al., 2011; Henneberger et al., 2012). Interestingly, the closest related pmoA sequences to the three USC $\gamma$ OTUs were all retrieved by Zheng et al. (2011) at the same study site, an alpine meadow at the Haibei Ecosystem research station on the Tibetan Plateau. The site has a mean annual temperature of $-2{ }^{\circ} \mathrm{C}$, and soils at this site are cryic cambisols typically occurring in permafrost areas. The single 
pmoA sequence of OTU5 is most closely related to a Cluster I pmoA sequence that was detected in deciduous forest soil, a net sink of atmospheric methane (Knief et al., 2006). It makes sense that this clone was retrieved from MRT 7, the only sample taken in a developing forest where the soil was older than 50 years.

The two sets of T-RFLP patterns from first- (Fig. S2) and second-round PCR (Fig. 4) compared well. Both sets of patterns consistently show the co-occurrence of the USC $\gamma$ assigned 241-bp and 339-bp T-RFs or dominance of the Methylocystis-assigned 243-bp T-RF. The co-occurrence of the Methylocystis-assigned 243-bp T-RF (pmoAl) and 350bp T-RF (pmoA2) can be observed only in the patterns from second-round PCR, because pmoA2 is not efficiently amplified by the primer pair A189f-A682r used in first round. We are therefore confident that the nested PCR approach generated a representative picture of MOB diversity in sampled glacier forefields. The relative abundances of the T-RFs in Fig. 4 corroborated the low diversity in the $p m o A$ sequences and reflected the strong dominance of USC $\gamma$. Surprisingly, USC $\gamma$ dominated even in sites with acidic $\mathrm{pH}$ (DAM and MRT), while in previous studies this group was primarily detected in neutral soil (Knief et al., 2003; Zheng et al., 2011). As Type I MOB tend to dominate MOB communities in cold environments (reviewed in Liebner and Wagner, 2010; Martineau et al., 2010; Yergeau et al., 2010), members of USC $\gamma$ might be widespread in cold ecosystem upland soils. A recent study also observed the prevalent occurrence of Type II Methylocystis in a permafrost active layer (Barbier et al., 2012). In our study, the occurrence of Methylocystis was restricted to a few glacier forefields on calcareous bedrock. Accordingly, $\mathrm{CH}_{4}$ concentrations at sampling depth $(10 \mathrm{~cm})$ were significantly higher for Methylocystis-dominated locations ( $\mathrm{p}$-value $=0.0019$; including all 27 samples). Growth of isolated strains of Methylocystis was restricted to $\mathrm{CH}_{4}$ concentrations $>10 \mu \mathrm{LL}^{-1}$ (Knief and Dunfield, 2005; Baani and Liesack, 2008). This would explain the limitation of Methylocystis to calcareous sites. As Methylocystis might have the ability to express different pMMO isozymes for low $\left(\sim 2-600 \mu \mathrm{LL}^{-1}\right)$ and high $\left(>600 \mu \mathrm{LL}^{-1}\right)$ $\mathrm{CH}_{4}$ concentrations (Baani and Liesack, 2008), one would also imply an advantage over USC $\gamma$ at higher $\mathrm{CH}_{4}$ availability. However, Methylocystis-dominated GRF 1 and 2 showed $\mathrm{CH}_{4}$ concentrations much lower than $10 \mu \mathrm{LL}^{-1}$ in $10 \mathrm{~cm}$ depth, and the USC $\gamma$-dominated WIL 4 exhibited the highest $\mathrm{CH}_{4}$ concentrations of all sites. Therefore, with the current data set, we cannot give a confident explanation for the occurrence of USC $\gamma$ or Methylocystis at calcareous sites. However, it should be noted that soil- $\mathrm{CH}_{4}$ concentrations and fluxes likely exhibit diurnal and seasonal variability not reflected by our one-time measurements (Friborg et al., 1997; Hendriks et al., 2010). Second, for most calcareous locations the active zone (largest shift in $\mathrm{CH}_{4}$ gradient) was much deeper than our sampled depth of $3-10 \mathrm{~cm}$. It will be interest- ing to analyze $p m o A$ diversity and abundance together with $\mathrm{CH}_{4}$ concentrations in a vertical profile.

\section{Conclusions}

Our results confirmed the presence of MOB in all sampled Swiss glacier forefields, while MOB activity was evident at many locations. Siliceous and calcareous forefields showed clearly different $\mathrm{CH}_{4}$ turnover patterns: while atmospheric $\mathrm{CH}_{4}$ oxidation accompanied by microsite methanogenesis was common at siliceous sites, all calcareous glacier forefields featured a deep-soil $\mathrm{CH}_{4}$ source of unknown origin, with $\mathrm{MOB}$ consuming up to $90 \%$ of $\mathrm{CH}_{4}$ before reaching the atmosphere. However, diversity of MOB was limited in both siliceous and calcareous forefields and was strongly dominated by the USC $\gamma$ group, while USC $\alpha$-like populations were not detected. Members of USC $\gamma$ might be widespread in cold climate upland environments.

Acknowledgements. We would like to thank Andreas Gauer, Isolde Erny and Martin Vogt, among others, for their invaluable help with field work. Bomba Dam is grateful to the Alexander von Humboldt Foundation for his fellowship. This project was funded by ETH Zurich (in part through grant no. TH-20 06-3), the Swiss National Science Foundation (grant no. 200021-137721), and the LOEWE Research Center for Synthetic Microbiology (SYNMIKRO). Helpful suggestions from reviewers S. Kolb, J. Yavitt and P. Bodelier were highly appreciated.

Edited by: Z. Jia

\section{Supplementary material related to this article is available online at: http://www.biogeosciences.net/9/ 2259/2012/bg-9-2259-2012-supplement..zip.}

\section{References}

Adamsen, A. P. S. and King, G. M.: Methane consumption in temperate and subarctic forest soils: Rates, vertical zonation, and responses to water and nitrogen, Appl. Environ. Microb., 59, 485490, 1993.

Andersen, B. L., Bidoglio, G., Leip, A., and Rembges, D.: A new method to study simultaneous methane oxidation and methane production in soils, Global Biogeochem. Cy., 12, 587-594, 1998.

Auman, A. J., Speake, C. C., and Lidstrom, M. E.: nifH sequences and nitrogen fixation in type I and type II methanotrophs, Appl. Environ. Microb., 67, 4009-4016, 2001.

Baani, M. and Liesack, W.: Two isozymes of particulate methane monooxygenase with different methane oxidation kinetics are found in Methylocystis sp. strain SC2, P. Natl. Acad. Sci. USA, 105, 10203-10208, 2008.

Barbier, B. A., Dziduch, I., Liebner, S., Ganzert, L., Lantuit, H., Pollard, W., and Wagner, D.: Methane-cycling communities in a permafrost-affected soil on Herschel Island, Western Canadian 
Arctic: Active layer profiling of $m c r A$ and $p m o A$ genes, FEMS Microbiol. Ecol., doi:10.1111/j.1574-6941.2012.01332.x, 2012.

Bárcena, T. G., Yde, J. C., and Finster, K. W.: Methane flux and high-affinity methanotrophic diversity along the chronosequence of a receding glacier in Greenland, Ann. Glaciol., 51, 23-31, 2010.

Bárcena, T., Finster, K., and Yde, J.: Spatial patterns of soil development, methane oxidation, and methanotrophic diversity along a receding glacier forefield, southeast Greenland, Arct. Antarct. Alp. Res., 43, 178-188, 2011.

Bender, M. and Conrad, R.: Kinetics of $\mathrm{CH}_{4}$ oxidation in oxic soils exposed to ambient air or high $\mathrm{CH}_{4}$ mixing ratios, FEMS Microbiol. Lett., 101, 261-270, 1992.

Bernasconi, S. M., Bauder, A., Bourdon, B., Brunner, I., Bünemann, E., Chris, I., Derungs, N., Edwards, P., Farinotti, D., Frey, B., Frossard, E., Furrer, G., Gierga, M., Göransson, H., Gülland, K., Hagedorn, F., Hajdas, I., Hindshaw, R., Ivy-Ochs, S., Jansa, J., Jonas, T., Kiczka, M., Kretzschmar, R., Lemarchand, E., Luster, J., Magnusson, J., Mitchell, E. A. D., Venterink, H. O., Plötze, M., Reynolds, B., Smittenberg, R. H., Stähli, M., Tamburini, F., Tipper, E. T., Wacker, L., Welc, M., Wiederhold, J. G., Zeyer, J., Zimmermann, S., and Zumsteg, A.: Chemical and biological gradients along the Damma glacier soil chronosequence, Switzerland, Vadose Zone J, 10, 867-883, 2011.

Boetius, A., Ravenschlag, K., Schubert, C. J., Rickert, D., Widdel, F., Gieseke, A., Amann, R., Jorgensen, B. B., Witte, U., and Pfannkuche, O.: A marine microbial consortium apparently mediating anaerobic oxidation of methane, Nature, 407, 623-626, 2000.

Born, M., Dörr, H., and Levin, I.: Methane consumption in aerated soils of the temperate zone, Tellus B, 42, 2-8, 1990.

Bourne, D. G., McDonald, I. R., and Murrell, J. C.: Comparison of pmoA PCR primer sets as tools for investigating methanotroph diversity in three Danish soils, Appl. Environ. Microbiol., 67, 3802-3809, 2001.

Brankatschk, R., Towe, S., Kleineidam, K., Schloter, M., and Zeyer, J.: Abundances and potential activities of nitrogen cycling microbial communities along a chronosequence of a glacier forefield, ISME J., 2010.

Conrad, R.: Soil microorganisms as controllers of atmospheric trace gases $\left(\mathrm{H}_{2}, \mathrm{CO}, \mathrm{CH}_{4}, \mathrm{OCS}, \mathrm{N}_{2} \mathrm{O}\right.$, and $\left.\mathrm{NO}\right)$, Microbiol. Mol. Biol. R., 60, 609, 1996.

Conrad, R.: The global methane cycle: Recent advances in understanding the microbial processes involved, Environ. Microbiol. Reports, 1, 285-292, 2009.

Costello, A. M. and Lidstrom, M. E.: Molecular characterization of functional and phylogenetic genes from natural populations of methanotrophs in lake sediments, Appl. Environ. Microbiol., 65, 5066-5074, 1999.

De Visscher, A., Boeckx, P., and van Cleemput, O.: Artificial methane sinks, in: Greenhouse gas sinks, edited by: Reay, D. S., Hewitt, C. N., Smith, K. A., and Grace, J., CABI, Wallingford, 184-200, 2007.

Dedysh, S. N., Ricke, P., and Liesack, W.: NifH and NifD phylogenies: an evolutionary basis for understanding nitrogen fixation capabilities of methanotrophic bacteria, Microbiology (SGM), 150, 1301-11313, 2004.

Degelmann, D. M., Borken, W., Drake, H. L., and Kolb, S.: Different atmospheric methane-oxidizing communities in European beech and Norway spruce soils, Appl. Environ. Microbiol., 76, 3228-3235, 2010.

Dlugokencky, E., Bruhwiler, L., White, J., Emmons, L., Novelli, P., Montzka, S., Masarie, K., Lang, P., Crotwell, A., and Miller, J.: Observational constraints on recent increases in the atmospheric $\mathrm{CH}_{4}$ burden, Geophys. Res. Lett., 36, L18803, doi:10.1029/2009GL039780, 2009.

Duc, L., Noll, M., Meier, B., Bürgmann, H., and Zeyer, J.: High diversity of diazotrophs in the forefield of a receding alpine glacier, Microb. Ecol., 57, 179-190, 2009.

Dunbar, J., Ticknor, L. O., and Kuske, C. R.: Phylogenetic specificity and reproducibility and new method for analysis of terminal restriction fragment profiles of 16S rRNA genes from bacterial communities, Appl. Environ. Microbiol., 67, 190-197, 2001.

Dunfield, P., Knowles, R., Dumont, R., and Moore, T. R.: Methane production and consumption in temperate and subarctic peat soils: Response to temperature and $\mathrm{pH}$, Soil Biol. Biochem., 25, 321-326, 1993.

Dunfield, P. F.: The soil methane sink, in: Greenhouse gas sinks, edited by: Reay, D., Hewitt, K., Smith, K., and Grace, J., CABI, Wallingford, 152-170, 2007.

Egli, M., Wernli, M., Kneisel, C., and Haeberli, W.: Melting glaciers and soil development in the proglacial area Morteratsch (Swiss Alps): I. Soil type chronosequence, Arct. Antarct. Alp. Res., 38, 499-509, 2006.

Etiope, G., and Klusman, R. W.: Geologic emissions of methane to the atmosphere, Chemosphere, 49, 777-789, 2002.

Ettwig, K. F., Butler, M. K., Le Paslier, D., Pelletier, E., Mangenot, S., Kuypers, M. M. M., Schreiber, F., Dutilh, B. E., Zedelius, J., de Beer, D., Gloerich, J., Wessels, H. J. C. T., van Alen, T., Luesken, F., Wu, M. L., van de Pas-Schoonen, K. T., Op den Camp, H. J. M., Janssen-Megens, E. M., Francoijs, K.-J., Stunnenberg, H., Weissenbach, J., Jetten, M. S. M., and Strous, M.: Nitrite-driven anaerobic methane oxidation by oxygenic bacteria, Nature, 464, 543-548, 2010.

Fechner, E. J. and Hemond, H. F.: Methane transport and oxidation in the unsaturated zone of a Sphagnum peatland, Global Biogeochem. Cy., 6, 33-44, 1992.

Flessa, H., Rodionov, A., Guggenberger, G., Fuchs, H., Magdon, P., Shibistova, O., Zrazhevskaya, G., Mikheyeva, N., Kasansky, O. A., and Blodau, C.: Landscape controls of $\mathrm{CH}_{4}$ fluxes in a catchment of the forest tundra ecotone in northern Siberia, Glob. Change Biol., 14, 2040-2056, 2008.

Forster, P., Ramaswamy, V., Artaxo, P., Berntsen, T., Betts, R., Fahey, D. W., Haywood, J., Lean, J., Lowe, D. C., Myhre, G., Nganga, J., Prinn, R., Raga, G., Schulz, M., and Van Dorland, R.: Changes in atmospheric constituents and in radiative forcing, in: Climate change 2007: The physical science basis. Contribution of working group I to the fourth assessment report of the intergovernmental panel on climate change, edited by: Solomon, S., Qin, D., Manning, Z., Chen, Z., Marquis, M., Averyt, K. B., Tignor, M., and Miller, H. L., Cambridge University Press, Cambridge, UK and New York, NY, USA, 2007.

Friborg, T., Christensen, T. R., and Søgaard, H.: Rapid response of greenhouse gas emission to early spring thaw in a subarctic mire as shown by micrometeorological techniques, Geophys. Res. Lett., 24, 3061-3064, 1997.

Fuller, E. N., Schettler, P. D., and Giddings, J. C.: New method for prediction of binary gas-phase diffusion coefficients, Ind. Eng. 
Chem., 58, 18-27, 1966.

Hanson, R. and Hanson, T.: Methanotrophic bacteria, Microbiol. Mol. Biol. R., 60, 439-471, 1996.

Hartmann, A., Buchmann, N., and Niklaus, P.: A study of soil methane sink regulation in two grasslands exposed to drought and $\mathrm{N}$ fertilization, Plant Soil, 1-11, 2010.

Henckel, T., Jackel, U., Schnell, S., and Conrad, R.: Molecular analyses of novel methanotrophic communities in forest soil that oxidize atmospheric methane, Appl. Env. Microbiol., 66, 18011808, 2000.

Hendriks, D. M. D., van Huissteden, J., and Dolman, A. J.: Multitechnique assessment of spatial and temporal variability of methane fluxes in a peat meadow, Agr. Forest Meteorol., 150, 757-774, 2010.

Henneberger, R., Lüke, C., Mosberger, L., and Schroth, M. H.,: Structure and function of methanotrophic communities in a landfill-cover soil. FEMS Microbiol. Ecol., doi:10.1111/j.15746941.2011.01278.x, 2012.

Hinkel, K. M., Paetzold, F., Nelson, F. E., and Bockheim, J. G.: Patterns of soil temperature and moisture in the active layer and upper permafrost at Barrow, Alaska: 1993-1999, Global Planet. Change, 29, 293-309, 2001.

Hodson, A., Boggild, C., Hanna, E., Huybrechts, P., Langford, H., Cameron, K., and Houldsworth, A.: The cryoconite ecosystem on the greenland ice sheet, Ann. Glaciol., 51, 123-129, 2010.

Holmes, A. J., Costello, A., Lidstrom, M. E., and Murrell, J. C.: Evidence that particulate methane monooxygenase and ammonia monooxygenase may be evolutionarily related, FEMS Microbiol. Lett., 132, 203-208, 1995.

Holmes, A. J., Roslev, P., McDonald, I. R., Iversen, N., Henriksen, K., and Murrell, J. C.: Characterization of methanotrophic bacterial populations in soils showing atmospheric methane uptake, Appl. Env. Microbiol., 65, 3312-3318, 1999.

Hormes, A., Müller, B. U., and Schlüchter, C.: The Alps with little ice: Evidence for eight holocene phases of reduced glacier extent in the central Swiss Alps, The Holocene, 11, 255-265, 2001.

IUSS Working Group WRB: World reference base for soil resources 2006, World Soil Resources Reports No. 103. FAO, Rome, 2006.

Joerin, U. E., Stocker, T. F., and Schlüchter, C.: Multicentury glacier fluctuations in the Swiss Alps during the Holocene, The Holocene, 16, 697-704, 2006.

Kammann, C., Grünhage, L., Jäger, H. J., and Wachinger, G.: Methane fluxes from differentially managed grassland study plots: The important role of $\mathrm{CH}_{4}$ oxidation in grassland with a high potential for $\mathrm{CH}_{4}$ production, Environ. Pollut., 115, 261273, 2001

Kammann, C., Hepp, S., Lenhart, K., and Müller, C.: Stimulation of methane consumption by endogenous $\mathrm{CH}_{4}$ production in aerobic grassland soil, Soil Biol. Biochem., 41, 622-629, 2009.

Klusman, R. W., Leopold, M. E., and LeRoy, M. P.: Seasonal variation in methane fluxes from sedimentary basins to the atmosphere: Results from chamber measurements and modeling of transport from deep sources, J. Geophys. Res., 105, 2466124670, 2000.

Knief, C. and Dunfield, P. F.: Response and adaptation of different methanotrophic bacteria to low methane mixing ratios, Environ. Microbiol., 7, 1307-1317, 2005.

Knief, C., Lipski, A., and Dunfield, P. F.: Diversity and activity of methanotrophic bacteria in different upland soils, Appl. Environ.
Microbiol., 69, 6703-6714, 2003.

Knief, C., Kolb, S., Bodelier, P. L. E., Lipski, A., and Dunfield, P. F.: The active methanotrophic community in hydromorphic soils changes in response to changing methane concentration, Environ. Microbiol., 8, 321-333, 2006.

Kolb, S., Knief, C., Dunfield, P. F., and Conrad, R.: Abundance and activity of uncultured methanotrophic bacteria involved in the consumption of atmospheric methane in two forest soils, Environ. Microbiol., 7, 1150-1161, 2005.

Kolb, S.: The quest for atmospheric methane oxidizers in forest soils, Environ. Microbiol. Reports, 1, 336-346, 2009.

Kristensen, A. H., Thorbjørn, A., Jensen, M. P., Pedersen, M., and Moldrup, P.: Gas-phase diffusivity and tortuosity of structured soils, J. Contam. Hydrol., 115, 26-33, 2010.

Lacelle, D.: Environmental setting, (micro)morphologies and stable $\mathrm{C}-\mathrm{O}$ isotope composition of cold climate carbonate precipitates A review and evaluation of their potential as paleoclimatic proxies, Quaternary Sci. Rev., 26, 1670-1689, 2007.

Lafrenière, M. and Sharp, M.: The concentration and fluorescence of dissolved organic carbon (DOC) in glacial and nonglacial catchments: Interpreting hydrological flow routing and DOC sources, Arct. Antarct. Alp. Res., 36, 156-165, 2004.

Lane, J. D.: 16s/23s rRNA sequencing, in: Nucleic acid techniques in bacterial systematics, edited by: Stackebrandt, E., and Goodfellow, M., John Wiley and Sons, New York, NY, 115-175, 1991.

Lazzaro, A., Abegg, C., and Zeyer, J.: Bacterial community structure of glacier forefields on siliceous and calcareous bedrock, Eur. J. Soil Sci., 60, 860-870, 2009.

Lazzaro, A., Gauer, A., and Zeyer, J.: A field-scale transplantation experiment to investigate structures of soil bacterial communities at pioneering sites, Appl. Environ. Microbiol., doi:10.1128/AEM.05778-11, 2011.

Le Mer, J. and Roger, P.: Production, oxidation, emission and consumption of methane by soils: A review, Eur. J. Soil Biol., 37, 25-5-0, 2001.

Liebner, S. and Wagner, D.: Permafrost - current and future challenges to study methanotrophy in permafrost-affected tundra and wetlands, in: Handbook of hydrocarbon and lipid microbiology, edited by: Timmis, K. N., Springer Berlin Heidelberg, $2173-$ 2179, 2010.

Ludwig, W., Strunk, O., Westram, R., Richter, L., Meier, H., Yadhukumar, Buchner, A., Lai, T., Steppi, S., Jobb, G., Förster, W., Brettske, I., Gerber, S., Ginhart, A. W., Gross, O., Grumann, G., Hermann, S., Jost, R., König, A., Liss, T., Lüßmann, R., May, M., Nonhoff, B., Reichel, B., Strehlow, R., Stamatakis, A., Stuckmann, N., Vilbig, A., Lenke, M., Ludwig, T., Bode, A., and Schleifer, K.-H.: ARB: A software environment for sequence data. Nucl. Acids Res., 32, 1363-1371, 2004.

Maisch, M., Wipf, A., Denneler, B., Battaglia, J., and Benz, C.: Die Gletscher der Schweizer Alpen: Gletscherhochstand 1850, aktuelle Vergletscherung, Gletscherschwund-Szenarien, vdf Hochschulverlag AG an der ETH Zürich, Zürich, 2000.

Martineau, C., Whyte, L. G., and Greer, C. W.: Stable isotope probing analysis of the diversity and activity of methanotrophic bacteria in soils from the Canadian High Arctic, Appl. Environ. Microbiol., 76, 5773-5784, 2010.

Matthews, M. D.: Migration - a view from the top, in: Hydrocarbon migration and its near-surface expression, edited by: Schumacher, D., and Abrams, M. A., Amer. Assoc. Petrol. Geol., 
Tulsa, OK, 139-155, 1996.

McDonald, I. R., Bodrossy, L., Chen, Y., and Murrell, J. C.: Molecular ecology techniques for the study of aerobic methanotrophs, Appl. Environ. Microbiol., 74, 1305-1315, 2008.

Moldrup, P., Olesen, T., Gamst, J., Schjonning, P., Yamaguchi, T., and Rolston, D. E.: Predicting the gas diffusion coefficient in repacked soil: Water-induced linear reduction model, Soil Sci. Soc. Am. J., 64, 1588-1594, 2000.

Moore, T. R. and Knowles, R.: Methane emissions from fen, bog and swamp peatlands in Quebec, Biogeochemistry, 11, 45-61, 1990.

Muller, R. N. and Hamilton, M. E.: A simple, effective method for determining the bulk density of stony soils, Commun. Soil Sci. Plan., 23, 313-319, 1992.

Nauer, P. A. and Schroth, M. H.: In situ quantification of atmospheric methane oxidation in near-surface soils, Vadose Zone J., 9, 1052-1062, 2010.

Nemergut, D., Anderson, S., Cleveland, C., Martin, A., Miller, A., Seimon, A., and Schmidt, S.: Microbial community succession in an unvegetated, recently deglaciated soil, Microb. Ecol., 53, 110-122, 2007.

Orphan, V. J., House, C. H., Hinrichs, K.-U., McKeegan, K. D., and DeLong, E. F.: Multiple archaeal groups mediate methane oxidation in anoxic cold seep sediments, P. Natl. Acad. Sci. USA, 99, 7663-7668, 2002.

Sawstrom, C., Mumford, P., Marshall, W., Hodson, A., and Laybourn-Parry, J.: The microbial communities and primary productivity of cryoconite holes in an arctic glacier (Svalbard $79^{\circ} \mathrm{N}$ ), Polar Biol., 25, 591-596, 2002.

Shrestha, P. M., Kammann, C., Lenhart, K., Dam, B., and Liesack, W.: Linking activity, composition, and seasonal dynamics of atmospheric methane oxidizers in a meadow soil, ISME J., doi:10.1038/ismej.2011.179, 2011.

Sigler, W. V., and Zeyer, J.: Microbial diversity and activity along the forefields of two receding glaciers, Microb. Ecol., 43, 397407, 2002.

Sims, G. K., Ellsworth, T. R., and Mulvaney, R. L.: Microscale determination of inorganic nitrogen in water and soil extracts, Commun. Soil Sci. Plan., 26, 303-316, 1995.

Smith, K. A., Dobbie, K. E., Ball, B. C., Bakken, L. R., Sitaula, B. K., Hansen, S., Brumme, R., Borken, W., Christensen, S., Priemé, A., Fowler, D., Macdonald, J. A., Skiba, U., Klemedtsson, L., Kasimir-Klemedtsson, A., Degórska, A., and Orlanski, P.: Oxidation of atmospheric methane in northern European soils, comparison with other ecosystems, and uncertainties in the global terrestrial sink, Glob. Change Biol., 6, 791-803, 2000.
Soil Survey Staff: Soil survey laboratory information manual. Soil survey investigations report no. 45, Version 2.0, edidet by: Burt, R., U.S. Department of Agriculture, Natural Resources Conservation Service, Lincoln, Nebraska, 2011.

Stibal, M., Lawson, E. C., Lis, G. P., Mak, K. M., Wadham, J. L., and Anesio, A. M.: Organic matter content and quality in supraglacial debris across the ablation zone of the greenland ice sheet, Ann. Glaciol., 51, 1-8, 2010.

Tchawa Yimga, M., Dunfield, P. F., Ricke, P., Heyer, J., and Liesack, W.: Wide distribution of a novel pmoA-like gene copy among type II methanotrophs, and its expression in Methylocystis strain SC2, Appl. Environ. Microbiol., 69, 5593-5602, 2003.

Urmann, K., Gonzalez-Gil, G., Schroth, M. H., and Zeyer, J.: Quantification of microbial methane oxidation in an alpine peat bog, Vadose Zone J., 6, 705-712, 2007.

Wadham, J. L., Cooper, R. J., Tranter, M., and Bottrell, S.: Evidence for widespread anoxia in the proglacial zone of an arctic glacier, Chem. Geol., 243, 1-15, 2007.

Wang, F. L. and Bettany, J. R.: Methane emission from canadian prairie and forest soils under short term flooding conditions, Nutr. Cycl. Agroecosys., 49, 197-202, 1997.

Whalen, S. C. and Reeburgh, W. S.: Consumption of atmospheric methane by tundra soils, Nature, 346, 160-162, 1990.

Whalen, S. C., Reeburgh, W. S., and Barber, V. A.: Oxidation of methane in boreal forest soils: A comparison of seven measures, Biogeochemistry, 16, 181-211, 1992.

Yavitt, J. B., Downey, D. M., Lang, G. E., and Sexston, A. J.: Methane consumption in two temperate forest soils, Biogeochemistry, 9, 39-52, 1990.

Yergeau, E., Hogues, H., Whyte, L. G., and Greer, C. W.: The functional potential of high arctic permafrost revealed by metagenomic sequencing, qPCR and microarray analyses, ISME J., 4, 1206-1214, 2010.

Zheng, Y., Yang, W., Sun, X., Wang, S.-P., Rui,Y. C., Luo, C. Y., and Guo, L. D.: Methanotrophic community structure and activity under warming and grazing of alpine meadow on the Tibetan Plateau. Appl. Microbiol. Biotechnol., doi:10.1007/s00253-0113535-5, 2011. 